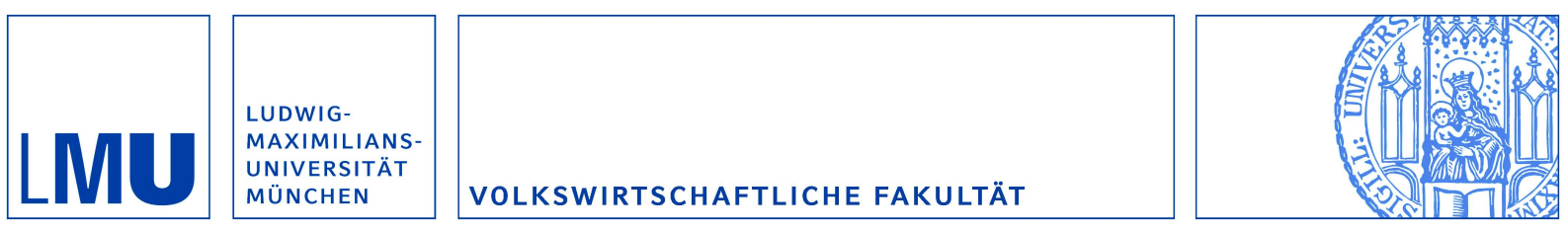

Asonuma, Tamon und Trebesch, Christoph:

Sovereign Debt Restructurings: Preemptive or Post-Default

Munich Discussion Paper No. 2015-18

Department of Economics

University of Munich

Volkswirtschaftliche Fakultät

Ludwig-Maximilians-Universitäł München

Online at https://doi.org/10.5282/ubm/epub.26563 


\title{
Sovereign Debt Restructurings: Preemptive or Post-Default
}

\author{
Tamon Asonuma* \\ Christoph Trebesch ${ }^{\text {II }}$
}

November 7, 2015

\begin{abstract}
Sovereign debt restructurings can be implemented preemptively - prior to a payment default. We code a comprehensive new dataset and find that preemptive restructurings (i) are frequent (38\% of all deals 1978-2010), (ii) have lower haircuts, (iii) are quicker to negotiate, and (iv) see lower output losses. To rationalize these stylized facts, we build a quantitative sovereign debt model that incorporates preemptive and post-default renegotiations. The model improves the fit with the data and explains the sovereign's optimal choice: preemptive restructurings occur when default risk is high ex-ante, while defaults occur after unexpected bad shocks. Empirical evidence supports these predictions.
\end{abstract}

JEL Classification Codes: F34, F41, H63

Key words: Sovereign Debt, Default, Debt Restructuring, Crisis Resolution

\footnotetext{
*International Monetary Fund, 700 19th Street, N.W. Washington, D.C. 20431 USA. tasonuma@imf.org

${ }^{\S}$ University of Munich, Schackstr 4, 80539 Munich, Germany. christoph.trebesch@lmu.de

${ }^{\top}$ We would like to thank the editor, two anonymous referees and Ali Abbas, Nikita Aggarwal, Manuel Amador, Charles Blitzer, Ran Bi, Marcos Chamon, Satyajit Chatterjee, Sergio Chodos, Aitor Erce, Burcu Eyigungor, Douglas Gale, Simon Gilchrist, Francois Gourio, Christoph Grosse Steffen, Oliver Jeanne, Jun Il Kim, Laurence Kotlikoff, Luc Laeven, Alberto Martin, Leonardo Martinez, Maurice Obstfeld, Ugo Panizza, Michael Papaioannou, Romain Ranciere, Carmen Reinhart, Francisco Roch, Damiano Sandri, Julian Schumacher, Cesar Sosa-Padilla, Cedric Tille, Adrien Verdelhan, Mark Wright and Vivian Yue for very helpful comments and suggestions. Maximilian Rupps provided excellent research assistance. All remaining errors are our own. The views expressed herein are those of the authors and should not be attributed to the IMF, its Executive Board, or its management.
} 


\section{Introduction}

Sovereign debt crises are a recurring feature of international capital markets, in particular in emerging market economies. In the past decades, debt crisis situations have often been solved by restructuring old debt at a discount, or "haircut". This paper shows that sovereign debt restructurings can be implemented in two main ways: preemptively or post-default. In post-default cases the government defaults first and then starts to renegotiate its debt later on. In contrast, preemptive restructurings are implemented prior to a unilateral payment default. The idea of preemptive restructurings plays a key role in the current policy debate on sovereign debt and default (Brookings-CIEPR 2013 and IMF 2013). However, there is still limited knowledge on preemptive debt exchanges and barely any research on different types of debt restructurings. This paper contributes to fill this gap. We classify preemptive vs. post-default restructurings in the data and produce a dynamic model of defaultable debt that incorporates these two asymmetric restructuring strategies.

The paper starts by presenting a comprehensive new dataset on sovereign debt restructurings with private external creditors over the past decades. We define preemptive and post-default restructurings and document our first stylized fact: that preemptive exchanges account for $38 \%$ of all restructurings between 1978 and 2010 (68 preemptive cases and 111 post-default cases). We also compile a new dataset on the duration of sovereign debt crises at a monthly frequency, which improves upon existing databases that are available only annually (e.g. Reinhart and Rogoff (2009)). Total duration is measured from the default or the announcement of a restructuring (start month) until the final debt exchange (end month). Furthermore, we merge existing datasets on creditor losses (haircuts), debtor country output, and government access to international capital markets.

The data show large differences between the two types of debt exchanges, summarized in four additional stylized facts. Preemptive restructurings are associated with significantly lower haircuts compared to post-default cases (18\% vs. $48 \%$ for post-default cases), a much shorter duration of debt renegotiation (1 year vs. 5 years), and significantly lower output losses (post-default cases see a protracted decline in GDP after crisis start, while preemptive cases do not). Furthermore, we show that preemptive restructurings see a quicker reaccess to international capital markets, as measured by the placement of bonds or syndicated loans with external creditors.

Our empirical findings pose a challenge for the theoretical literature on sovereign debt. Why are not more restructurings preemptive, if this type of renegotiation is shorter and if it goes along with lower output losses and facilitates market (re)access? Why do governments ever default unilaterally, if the preemptive option exists? To address these questions, we construct a dynamic stochastic general equilibrium model with endogenous default risk that extends the literature by allowing for a preemptive restructuring option, as observed in the data. We embed two asymmetric renegotiation strategies (before and after default) in an otherwise standard small open economy sovereign debt model that builds on related 
work such as Aguiar and Gopinath (2006) and Arellano (2008), and based on the classic framework by Eaton and Gersovitz (1981). The model features endogenous defaults and endogenous renegotiations where an emerging market country borrows abroad and is subject to exogenous income shocks as in Benjamin and Wright (2009), D'Erasmo (2010) or Yue (2010). The two renegotiation types (preemptive and post-default) both involve a Nash bargaining between the sovereign debtor and foreign private creditors over haircuts (recovery rates) and, implicitly, over the duration of debt renegotiation. The timing of the model is simple but differs from previous approaches in the literature: the choice of initiating a preemptive restructuring is taken ex-ante, before the income realization, while the decision of defaulting and restructuring later on is taken ex-post, after the income realization.

The main purpose of our model is to explain the choice to restructure preemptively or post-default. This decision is driven by considerations on the costs of financial exclusion and output losses in both types of debt restructurings, as well as by the expected recovery rates (haircuts/debt relief). We endogenize the restructuring decision and also the size of haircuts and the duration of renegotiation/exclusion. The only exogenous component is the size of output costs, which we assume to be higher in post-default cases. Specifically, we follow the convention in previous work and assume that a default triggers an output reduction of $2 \%$ in each period (Sturzenegger 2004). The output cost in preemptive (non-default) renegotiation is assumed to be lower, at $1.5 \%$ per period, an assumption that builds on our empirical findings.

The model predicts that a government will initiate a preemptive debt restructuring today when it has a high probability of default tomorrow. If a default is likely, the sovereign anticipates the high potential costs of a post-default crisis, in particular the long period of financial exclusion and the larger output losses. To avoid a messy default, the sovereign can renegotiate preemptively, even though the preemptive option implies a (short) exclusion from capital markets and (low) output losses that occur with certainty. Preemptive renegotiations can also be optimal for creditors, if the recovery rate they receive in the preemptive deal is higher than the present value of the debt they hold, i.e., if a high haircut is expected ex-post. The country and its creditors can also decide to wait and forgo the option to restructure preemptively. This is optimal when it is likely that the debt will be serviced in full, meaning at a low or moderate default probability ex-ante. In this situation, the expected costs of a preemptive restructuring are higher than the expected costs of an (unlikely) default. However, if an income shock is bad eventually, the sovereign will default and proceed to a post-default renegotiation process. The result will be longer financial exclusion, higher output costs, and a high haircut for creditors (more debt relief for the debtor country).

The model also explains why preemptive renegotiation results in lower haircuts and why they are quicker to negotiate. Preemptive deals imply lower haircuts because creditors have an attractive outside option: they can always reject the offer, wait, and hope for a good income realization and full repayment. The terms of a preemptive offer must be sufficiently 
attractive to be accepted by creditors ex-ante, at least equivalent to the expected return on the bonds in the absence of a preemptive deal. Sovereigns will offer worse terms and achieve more debt relief once a default occurs, because creditors have no choice but to accept a haircut or receive nothing on the defaulted debt. With regard to negotiation delays, preemptive deals are quicker to conclude in our model, due to the lower output costs in this type of renegotiation and because no arrears accumulate. This improves the repayment capacity of the sovereign and thus the probability of settling the debt quickly. In contrast, post-default cases see a slower recovery and, thus, longer delays. The mechanism is the same as in Benjamin and Wright (2009) and Bi (2008), where both creditors and debtors wait to restructure until output recovers and subsequent default risk is low.

The data confirm the main prediction of the model: countries with a high default risk, as measured by lagged changes in debt/GDP, credit ratings, growth, and terms of trade, are significantly more likely to restructure preemptively. This is not the case for post-default cases, which are harder to predict with lagged data. Our quantitative analysis also succeeds in replicating moments that match the data of two recent debt crises, namely Argentina's post-default crisis of 2001-2005 and Uruguay's preemptive restructuring of 2003. The simulations correctly predict a shorter duration and lower haircuts in preemptive deals.

Related literature: The paper builds on a large body of theoretical work on sovereign debt. In the literature, debt crises are typically modeled as discrete events in which a country either pays back or defaults on $100 \%$ of the debt (e.g. Eaton and Gersovitz (1981), Aguiar and Gopinath (2006), Tomz and Wright (2007) or Arellano (2008), see also the survey by Aguiar and Amador (2014)). Here, we focus on an intermediate outcome: restructurings without default, which occur with surprising frequency. ${ }^{1}$ Our theoretical setup is particularly related to papers that model a bargaining game between a sovereign debtor and its creditors (e.g. Bulow and Rogoff (1989), Benjamin and Wright (2009), Kovrijnykh and Szentes (2007), Bi (2008), Bai and Zhang (2010), D’Erasmo (2010), Yue (2010), Pitchford and Wright (2012), Asonuma (2012), Arellano and Bai (2014), and, in particular, Hatchondo et al. (2014)). Most of these papers simply assume that restructurings are preceded by a default, which is often not true, as shown here. ${ }^{2}$ To our knowledge, we are the first to incorporate two types of asymmetric negotiations (preemptive and post-default) into this literature.

\footnotetext{
${ }^{1}$ See Arellano et al. (2013) for an analysis of partial defaults, and Fernandez and Martin (2014) for a model that considers maturity extensions as an alternative to defaulting.

${ }^{2}$ Hatchondo et al. (2014) focus on "voluntary" sovereign debt exchanges, which they define as an exchange in which (i) the government does not miss any debt payment, (ii) there is a decline in the government's debt burden, and (iii) there are capital gains from participating in the restructuring. In their setup, the decision for a voluntary debt exchange is made simultaneously with the default choice. In contrast, in our model a preemptive restructuring is always made ex-ante (prior to the income realization) and, thus, prior to a potential default (which occurs ex-post). This time structure is closer in spirit to the empirically observed patterns of preemptive debt restructurings that we focus on here. Moreover, we choose a more general definition of pre-default restructurings (in line with Panizza et al. (2009) or the IMF (2013)) and provide a new dataset that goes back to the 1970s.
} 
In the empirical literature the paper is related to Sturzenegger and Zettelmeyer (2006), Finger and Mecagni (2007), Diaz-Cassou et al. (2008), Panizza et al. (2009), Das et al. (2012), Duggar (2013) and Erce (2013), which all study preemptive and post-default restructurings based on recent case studies. ${ }^{3}$ Using a narrower sample, Diaz-Cassou et al. (2008) argue that, when deciding whether to restructure preemptively or post-default, countries face a trade-off between larger debt relief and a faster recovery of market access. Our results are consistent with this interpretation, although we do not show causal effects. Instead, our main empirical contribution is that we are the first to provide stylized facts on preemptive vs. post-default renegotiations that are representative for the past four decades. In addition, we propose a refinement to the empirical measurement of preemptive restructurings, by distinguishing between strictly preemptive cases (no missed payments) and weakly preemptive cases (minor missed payments and negotiated payment suspensions).

We also provide new evidence on the output costs during sovereign debt crises, which have been studied by Sturzenegger (2004), Tomz and Wright (2007), Borensztein and Panizza (2009), De Paoli et al. (2009) and Levy-Yeyati and Panizza (2011). The distinction between types of debt crisis has not been made in previous quantitative work, and we find indication that preemptive debt restructurings trigger less "collateral damage" than postdefault cases. ${ }^{4}$ This is consistent with theories that assume proportional (not lump-sum) costs of default (e.g. Calvo (1988), Bulow and Rogoff (1989), Bolton and Jeanne (2007, 2009), Corsetti and Dedola (2013), Arellano et al. (2013)). More severe debt crisis cases also see a more severe decline in GDP.

\section{A New Dataset of Sovereign Debt Restructurings}

\subsection{Definitions: Preemptive vs. Post-default Restructurings}

In theory, a preemptive debt restructuring can be easily defined: it is a restructuring in which a debtor exchanges outstanding debt without missing any contractual payment towards the creditors involved. In practice, however, the classification of preemptive sovereign debt restructurings is complicated due to borderline cases. Restructurings can involve minor arrears, e.g. due to a temporary suspension of payments in the final weeks of an exchange offer. Such restructurings with minor missed payments or negotiated debt roll-overs have often been classified as preemptive in the past.

One example for a borderline case is Belize 2006-07, which involved missed payments, but was nevertheless coded as a preemptive restructuring in case studies by Diaz-Cassou et al. (2008), Das et al. (2012), IMF (2013) and Asonuma et al. (2014). The government of Belize announced to restructure its bonds in August of 2006, initiated negotiations with

\footnotetext{
${ }^{3}$ In smaller subsamples of restructurings since 1998, Finger and Mecagni (2007), Diaz-Cassou et al. (2008), Duggar (2013), and Erce (2013) also find that haircuts are lower and the restructuring processes faster in preemptive deals.

${ }^{4}$ Using case studies, Erce (2013) finds indication that GDP dynamics are worse following post-default restructurings. Ongoing work by Trebesch and Zabel (2014) builds on these findings and conducts a more extensive empirical analysis on the output costs of different types of sovereign default.
} 
major creditors in that same month and ceased interest payments on its bonds in early December of 2006. The payment suspension thus occurred just prior to the finalization of its debt exchange in January of 2007, but more than three months after the start of negotiations. In addition, the government announced that all missed payments were to be fully repaid in cash as part of the exchange and the creditor committee agreed to the temporary payment suspension. For these reasons the renegotiation process in Belize clearly differs from the typical post-default case in our data, in which sovereigns incur arrears unilaterally, without prior consultations with creditors and for prolonged periods. Belize 2006-07 can thus be regarded as a preemptive restructuring, despite the fact that payments were missed.

To account for such borderline cases and to classify restructurings as accurately as possible, it is helpful to distinguish between "strictly preemptive" and "weakly preemptive" cases. These are defined as follows:

- "Strictly preemptive" restructurings are those which are implemented with no missed payments at all (no legal default).

- "Weakly preemptive" restructurings are those in which some payments are missed, but only temporarily and after the start of formal or informal negotiations with creditor representatives (no unilateral default).

- "Post-default restructurings" are all other cases, in which payments are missed unilaterally and without the agreement of creditor representatives (unilateral default prior to negotiations).

Hereafter, preemptive restructurings will be broadly defined as including both "weakly" and "strictly" preemptive cases, while all other cases, those involving unilateral defaults, will be regarded as post-default restructurings.

\subsection{Coding Preemptive Restructurings}

Throughout the paper we focus on default and distressed debt restructurings between sovereigns and private external creditors such as international banks or bondholders. ${ }^{5}$ Our starting point to classify preemptive vs. post-default cases is the dataset by Cruces and Trebesch (2013), thus covering 179 deals in the 1978-2010 period. For each of these cases we then code whether they were strictly preemptive, weakly preemptive or post-default. A main challenge for this coding exercise was the lack of good quality data on missed payments by governments vis-à-vis private creditors. The World Bank's Global Development Finance (GDF) database does provide annual arrears data, but the arrears are not broken down by type of debtor, so it is not possible to distinguish between external arrears by the public sector and those by the domestic private sector (see the discussion in Manasse and Roubini,

\footnotetext{
${ }^{5}$ Debt swaps with external creditors, such as the Argentine "Megaswap" of 2001, are not included in our restructuring sample because they are not classified as a default or "distressed debt exchange" according to S\&P. The "Megaswap" in Argentina, for example, did not imply a haircut for creditors.
} 
2009). Moreover, the GDF arrears data are only available annually, at end-of-year values, so that any missed payments that are "cured" within the same year are not disclosed (i.e. any missed payments that are settled before December).

To classify preemptive restructurings, we therefore combine the limited quantitative yearly data on arrears and default from GDF and Standard \& Poor's (S\&P), with rich qualitative information from a broad range of sources. A particularly important qualitative source for us was the financial press archive gathered by Enderlein et al. (2012) which covers 100 of the 179 restructurings, as well as the case database by Trebesch (2013). Finally, we draw on reports from the IMF archives ${ }^{6}$ as well as books, policy reports and case studies, in particular Friedman (1983), Stamm (1987), Rieffel (2003), Roubini and Setser (2004), Sturzenegger and Zettelmeyer (2006), Diaz-Cassou et al. (2008), Reinhart and Rogoff (2009), Das et al. (2012), and Duggar (2013). The coding decision is documented in detail for each of the 179 restructurings, and backed by the exact sources used for coding. Appendix A shows coding examples and the underlying sources for a few exemplary cases.

\subsection{A Monthly Debt Crisis Dataset: Restructuring Duration 1978-2010}

As part of this paper we also compile a new monthly dataset on the duration of defaults and restructuring processes between governments and their foreign private creditors. Specifically, we update and expand the previous duration dataset by Trebesch $(2011,2013)$ and code the start and end of all 179 sovereign debt restructurings on a monthly basis (thus covering all deals in the Cruces and Trebesch (2013) dataset, spanning 1978-2010).

The start of a restructuring process is defined as the default month and/or the month in which a distressed restructuring is announced, where distressed restructurings are those involving terms that are less favorable than the original terms of the bonds or loans (this definition follows Standard \& Poor's and is also used in Cruces and Trebesch (2013)). More precisely, we code the start of a restructuring whenever (i) the government misses first payments to private external creditors beyond the grace period (default month) (ii) or whenever a key member of government publicly announces a debt restructuring. Both events indicate that the government is in severe financial distress.

The end of a restructuring is defined as the month of the final agreement and/or the implementation of the debt exchange. More precisely, we code the end month of a restructuring (i) as the month in which either an official signing ceremony took place (in the case of bank debt restructurings), or (ii) as the month in which the debt was ultimately exchanged on the market (in the case of bond restructurings).

Our duration dataset has two main advantages compared to existing ones, e.g. by

\footnotetext{
${ }^{6}$ We use a series of reports on "External Payments Arrears of Fund Members", as well as a 1983 report on "Payments Difficulties Involving Debt to Commercial Banks", which contains helpful information on the dates and scope of missed payments. Further helpful IMF sources were country-specific staff reports including the "Recent Economic Development" series. The IMF archives were particularly helpful for the early to mid-1980s and for highly indebted poor countries (HIPCs), where press coverage is typically scarce. Note that our main stylized facts and regression results remain qualitatively the same if we drop these poorest debtors.
} 
Standard \& Poor's (2006) and Reinhart and Rogoff (2009). First, it is the first comprehensive debt crisis dataset on a monthly (instead of yearly) level. Second, we code the duration of individual restructuring processes, which enables a more detailed analysis of crisis resolution processes. S\&P does not code the duration or finalization of negotiations. Instead, they lump together yearly debt crisis observations, so that it is not possible to disentangle restructuring events from events of missed payments. For example, Uruguay 2003 is coded as a default, even though the country did not miss any payments. ${ }^{7}$

For coding, we use the same set of sources described above. The financial press was particularly helpful to identify the month of default or restructuring announcement, although we faced limitations in 50 out of the 179 cases. $^{8}$ The resulting dataset will be made publicly available with a case by case list of sources used.

\section{Empirical Results: Five Stylized Facts}

Our findings for 1978-2010 can be summarized in five main stylized facts:

- Stylized Fact 1: Preemptive debt restructurings are frequent, accounting for more than a third of all sovereign debt exchanges since 1978.

We find that out of the 179 sovereign debt restructurings with foreign private creditors:

- 68 restructurings were preemptive (38\% of all cases), of which

- 23 restructurings were strictly preemptive (no payments missed)

- 45 restructurings were weakly preemptive (some missed payments, but no unilateral default)

- 111 restructurings occurred post-default (62\% of all cases)

Preemptive restructurings were particularly widespread during the 1970s and 1980s. About $50 \%$ of all cases in these years were either strictly or weakly preemptive (48 out of the 98 cases prior to 1990). One explanation for this is that creditors at the time were not valuing their claims at market prices and therefore had a keen interest in avoiding payment suspensions. Outright defaults obliged them to classify their sovereign loans and

\footnotetext{
${ }^{7}$ Moreover, we consider individual restructurings on different types of debt as separate processes if the negotiation and debt exchange process is conducted separately (bonds or loans, or different types of bonds). Depending on the question at hand, one can of course still choose to collapse restructuring spells into yearly debt crisis spells, as we will do in our panel analysis of output and market access below. Note also that the dataset follows Cruces and Trebesch (2013) and only includes defaults that result in a sovereign debt restructuring that is implemented. Please see the appendix of Cruces and Trebesch (2013) for a list of cases not included, such as Cuba, Liberia or Sudan, which have been in continuous default with no debt exchange since the $1980 \mathrm{~s}$.

${ }^{8}$ For 50 cases the exact starting month proved difficult to code, mostly in the 1970s and 1980s and in poor countries with little foreign commercial debt. We then set the starting month to June as our best guess and clearly disclose these cases by coding a dummy on "missing start month". No such measurement issues arise with regard to the end month since we know the exact restructuring date for all 179 cases.
} 
bonds as "value-impaired", to write off the positions and, thus, to take a loss on their books (Sachs and Huizinga (1987)). During the era of Brady deals (1990-1997), only 19\% of restructurings were preemptive (9 out of 48 ). The share increased again to about $30 \%$ in the most recent restructuring era (1998-2010).

Regarding the type of creditor, we find that recent bond restructurings have often been preemptive in nature. $50 \%$ of all bond restructurings in our sample were preemptive, namely 9 out of a total 18 , and 5 of these involved not a single missed payment (strictly preemptive). In contrast, only $37 \%$ of bank debt restructurings were preemptive (59 out of 161). Debtor characteristics also matter. In poor countries with limited access to international capital markets (HIPC or IDA countries) preemptive deals account for only $15 \%$ of all deals. The share is $48 \%$ in middle and higher income countries.

Appendix B summarizes the coding results for a selection of 16 recent restructurings, including 9 preemptive deals. Among the recent episodes, the Argentine debt restructuring of 2005 is a prominent post-default case, whereas the debt restructuring of Uruguay in May 2003 is a well-known preemptive case (classified as strictly preemptive here). We will focus on these two cases in our quantitative analysis of Section 6 .

Many preemptive restructurings are successful in the sense that they are not followed by a subsequent payment default by the same sovereign. In the full sample, we find that $64 \%$ of preemptive debt exchanges succeeded in preventing an outright default within four years after their completion (using the default dates in our own dataset as benchmark). Figure C.1 in the appendix shows the restructuring history of each country from 1978 to 2010.

Table 1: Duration and Haircuts for Preemptive vs. Post-default Cases

\begin{tabular}{|c|c|c|c|c|c|c|}
\hline & Obs & Mean & Median & Std. Dev. & Min & Max \\
\hline \multicolumn{7}{|c|}{ Haircuts (percent) } \\
\hline Preemptive & 68 & 18.4 & 15.5 & 15.5 & -9.8 & 56.3 \\
\hline Post-Default & 111 & 48.0 & 42.6 & 26.6 & -2.8 & 97 \\
\hline \multicolumn{7}{|c|}{ Duration of Restructurings (months) } \\
\hline Preemptive & 68 & 12.2 & 12.0 & 6.5 & 2 & 30 \\
\hline Post-Default & 111 & 59.8 & 37.0 & 58.6 & 4 & 272 \\
\hline
\end{tabular}

\section{- Stylized Fact 2: Preemptive debt restructurings have much lower NPV haircuts, with an average NPV haircut of just $18 \%$.}

Table 1 summarizes the haircut data by Cruces and Trebesch (2013) and our new monthly dataset on restructuring duration. Creditor losses are much higher in post-default cases, with a mean haircut of $48 \%$, more than twice as high. We also find that most preemptive restructurings do not involve a nominal haircut (face value reduction). Figure 
C.2 in the appendix shows a scatter plot of haircuts for both type of restructurings 1978-2010.

- Stylized Fact 3: Preemptive debt restructurings have a much shorter duration, taking one year to complete, on average.

On average, preemptive deals take 12 months from start to end, with a maximum of 30 months. This compares to an average duration of 60 months for post-default cases, with a maximum of 272 months (more than 20 years) from default until the debt exchange. These notable differences can also be illustrated by plotting an empirical survival function, as in Figure C.3 in the appendix. The estimates show that preemptive restructurings have a significantly higher probability of being completed at each point in time.

Figure 1: Duration and Haircuts for Preemptive vs. Post-default Cases

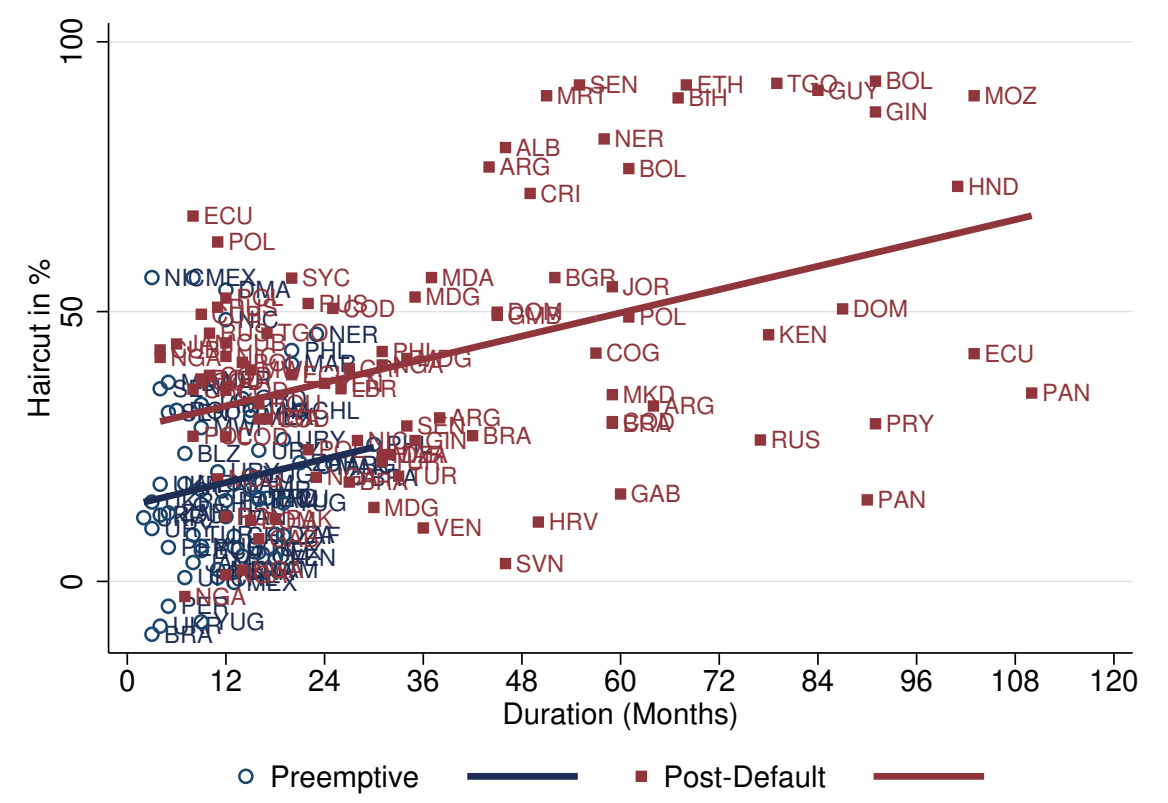

We next combine the data on haircut size with that on restructuring duration. Benjamin and Wright (2009) were the first to show that longer sovereign debt crises (renegotiation delays) are typically associated with higher haircuts. This stylized fact can be confirmed based on our new data and using a sample of 179 instead of their 90 events. Figure 1 shows a scatter plot of haircuts and restructuring delays, differentiating between preemptive and post-default cases. Interestingly, the correlation between haircuts and delays is strong in both subsamples, with a fitted line that has an almost identical positive slope for both types of deals. However, the intercept is significantly lower for preemptive cases.

- Stylized Fact 4: Preemptive debt restructurings are associated with significantly lower output losses. 
Our fourth stylized fact focuses on output losses during default. ${ }^{9}$ The theoretical literature mostly assumes that sovereign defaults have lump-sum output costs, which do not depend on the type of default. In line with this approach, previous empirical papers have mostly used a binary dummy to study the output costs of debt crises (default vs. non-default). Our innovation here is to distinguish by the type of default.

Figure 2 shows that there are notable differences in the output performance of preemptive and post-default crisis spells. In both panels, the start of the crisis (the default or restructuring announcement) is denoted with year 0 on the horizontal axis and marked by a gray vertical bar. ${ }^{10}$ The resulting GDP sample includes all 145 restructuring events for which growth data was available from the World Bank's World Development Indicators (WDI). Note also that the gray dashed line is cut off after the second crisis year, since there are only very few preemptive cases that take longer than two years to conclude.

Figure 2: Output and Growth: Preemptive vs. Post-Default Cases

Panel A: Dynamics of Real GDP per capita (=100 at crisis start)

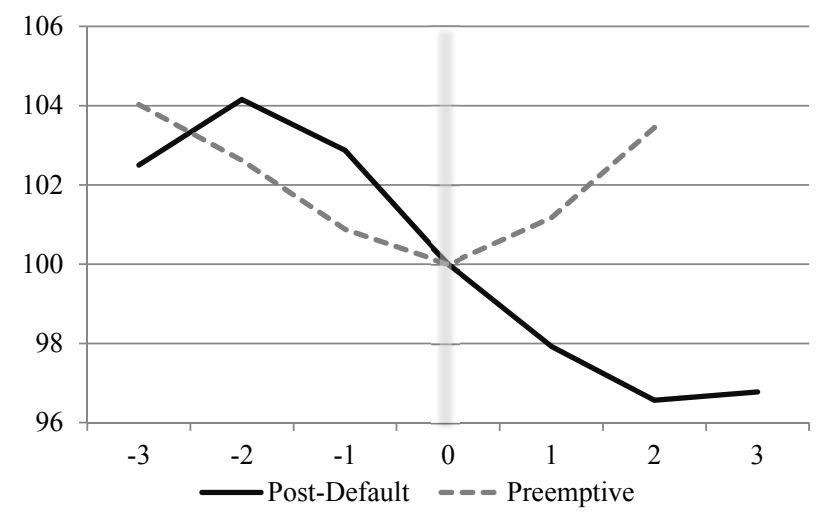

Panel B: GDP Deviation from Trend (real, per capita)

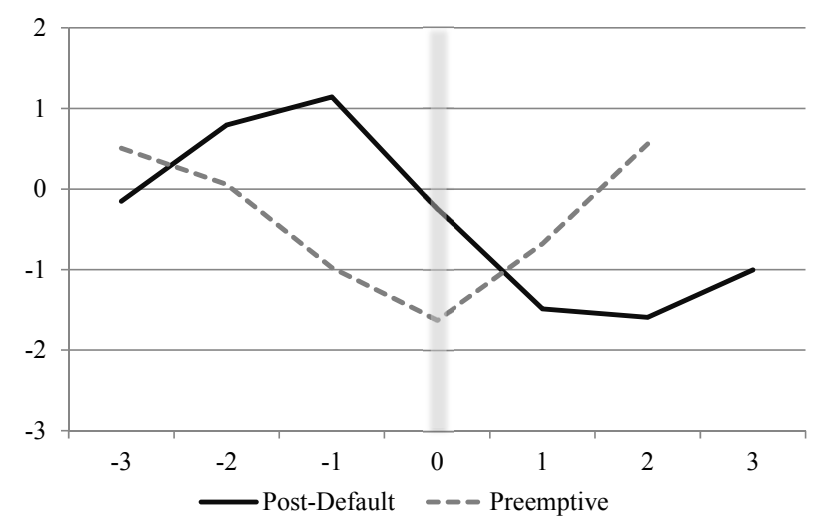

Panel A shows that real GDP per capita declines more markedly in the run up to preemptive debt crisis cases. At the same time, output starts to recover right after the

\footnotetext{
${ }^{9}$ The stylized facts presented in this section are not necessarily causal. We do not claim to identify an effect from the preemptive restructuring/default decision to macroeconomic outcomes.

${ }^{10}$ For the purpose of this analysis, we collapsed the restructuring spells into yearly crisis spells.
} 
start of preemptive renegotiations and quickly reaches its pre-crisis level. This contrasts with post-default cases where output drops notably at the onset of default and in the two subsequent years. The cumulative decline in real output is much larger for post-default cases, which see a GDP drop of nearly 8 percentage points in the four years around the start of default.

Panel B confirms this picture using data on GDP deviation from trend (in percent), where GDP trend is computed using a standard Hodrick-Prescott filter with 6.25 as smoothing parameter. Again we find growth to decline in the run-up to preemptive debt crisis spells and to recover quickly thereafter. In contrast, for post-default crises, GDP deviation from trend turns negative at the onset of default and remains significantly below trend in the three subsequent years.

Additional evidence is shown in Table D.1 in the appendix, which reports results of a standard fixed effects panel regression of real per capita growth on debt crises for 1980-2009 and including a sample of 138 developing countries with a population above 500,000 . Of these countries 75 had at least one debt restructuring, while 63 never defaulted or restructured. Column (1) shows results for a bare-bones model with country and year fixed effects and dummies for the current and lagged start of a debt crisis (using our own crisis database). ${ }^{11}$ In Column (2) we add a standard set of growth controls used also by Sturzenegger (2004), Borensztein and Panizza (2009) and others, in particular on population, investment to GDP, consumption, trade openness ((exports+imports)/GDP) (all from WDI), secondary education (from the Barro-Lee dataset), an index of civil liberties (by Freedom House), as well as dummies for the onset of banking crises and currency crises from Leaven and Valencia (2012). The dataset we use here was compiled for Trebesch and Zabel (2014).

For the full sample, the results are very similar to previous findings: sovereign debt crises are associated with $2 \%$ lower annual growth in the first two crisis years. However, we find notable differences between preemptive and post-default cases. The results in Columns (3) and (4) support the view that the announcement of a preemptive debt restructuring does not trigger significant output losses. The coefficient for the onset of preemptive restructurings is only negative in year one and at the $10 \%$ significance level only. The point estimate is -1.4 , suggesting short-lived $1.4 \%$ decline in growth. On the contrary, post-default crises are associated with a substantial decline in output of at least $2 \%$ (in the conservative specification of Column (6)).

\section{- Stylized Fact 5: Preemptive debt restructurings are associated with shorter periods of market exclusion.}

We also assess government exclusion from capital markets. For this purpose, we draw on two separate datasets on market access. First, we use the approach and data in Cruces and Trebesch (2013) and focus on the duration of government reaccess in the aftermath of

\footnotetext{
${ }^{11}$ If a sovereign defaults on some parts of its debt (e.g. bank loans) but not on other obligations (e.g. Eurobonds) we nevertheless code that year as a post-default event.
} 
65 final restructurings, defined as those restructurings that effectively cured the default event. Duration is computed as the number of years between a final restructuring and partial market reaccess, measured as the first year with an international loan or bond placement (using micro data from Dealogic) and/or the first year with positive aggregate credit flows to the public sector (using macro data from the World Bank), see Cruces and Trebesch (2013) for details. ${ }^{12}$ Here we assess whether the duration of reaccess depends on the type of crisis. Figure 3 reports statistics from a standard non-parametric Kaplan-Meier estimator, where the vertical axis shows the cumulative probability of not having reaccessed the market for each year after the restructuring. The main message from this figure is that reaccess post-crisis is significantly quicker after preemptive deals.

Figure 3: Reaccessing Capital Markets after Restructurings

The figure plots estimated Kaplan-Meier survival functions for the duration of capital market exclusion following preemptive and post-default restructurings (for 65 final deals 1980-2009). The y-axis denotes the compound probability that countries remain excluded for each year after the restructuring.

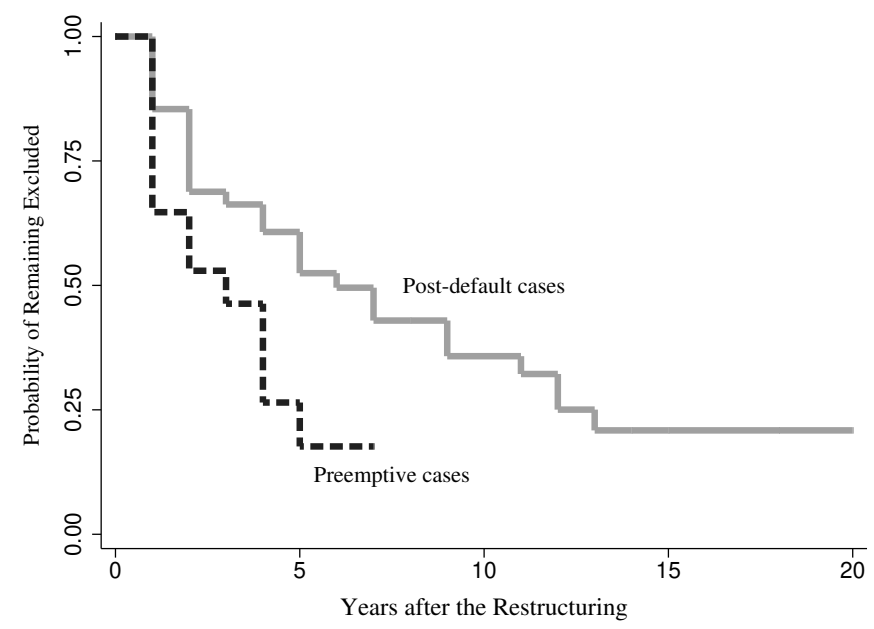

Our second approach aims to shed light on within-crisis exclusion. For this purpose, we closely follow the empirical strategy in Gelos et al. (2011) and use the panel dataset of market access compiled by Schumacher et al. (2014) for 144 countries between 1980 and 2010. The dependent variable now measures access in any given year, meaning before, during, and after debt crises. The dummy is 1 whenever sovereigns place a bond or syndicated loan abroad, and zero otherwise, where access to international capital markets is measured from more than 20,000 sovereign bonds and loans from the comprehensive Dealogic database. Like in our panel regressions on economic growth, we collapse observations by country into yearly crisis episodes; we include country and year fixed effects in all regressions; we drop countries with a population below 500,000; and we show results both with and without controls, where the set of controls builds on the received literature, in particular Gelos et

\footnotetext{
${ }^{12}$ We measure market re-access after the restructuring as observed in the data. This includes episodes where re-access was temporary and lost again (a recent such example is Greece in 2014, following the 2012 restructuring).
} 
al. (2011). Table E.1 in the appendix shows the results using panel fixed effects OLS (the findings are similar with a fixed effects logit model).

The main result is that sovereigns lose market access in any ongoing debt crisis, whether it is a preemptive or post-default process. This implies that longer negotiation delays also translate into longer periods of market exclusion (1 year for preemptive deals vs. 5 years for post-default cases, see above). For example, the first coefficient in Column (4) of Table E.1 (-0.36) indicates that the probability of market access is 36 percentage points lower during years with ongoing preemptive debt renegotiations. This compares to an average probability of $37 \%$ of accessing markets in each given year in this subsample. Put differently, the likelihood of issuing external debt decreases to almost zero in crisis years. ${ }^{13}$ At the same time, we can confirm that reaccess is significantly more likely after preemptive deals, as indicated in Figure 3 above. The lagged crisis measure in Columns (3) and (4) is insignificant for preemptive crisis spells, but it is highly significant and with a large negative coefficient for post-default cases (Column (5) and (6)). We thus conclude that post-default cases clearly see longer exclusion, both within-crisis (the process is more protracted) and due to delayed reaccess post-crisis.

\section{Theoretical Model}

\subsection{Intuition}

In this section we present a model that allows for preemptive and post-default restructurings and incorporates the above stylized facts. Our first and main purpose of the model is to explain the choice of restructuring technique. Why and when do sovereigns opt to restructure preemptively? In our model, the mechanism driving this restructuring choice is as follows: in distress, sovereigns face a trade-off between initiating a preemptive deal ex-ante or not. Preemptive deals help to avoid a costly and protracted default ex-post, but they come at an immediate and certain cost: a (short) exclusion from capital markets and a (lower but certain) output decline. Moreover, the sovereign can expect to negotiate only a small haircut (little debt relief) in preemptive restructurings, so that the costs of repaying the restructured debt will be higher than in post-default cases. This trade-off results in a situation where preemptive exchanges can be optimal, depending on the expected costs of a default and the expected size of haircuts negotiated in both types of restructurings.

The (risk-neutral) creditors also face a trade-off when choosing whether to accept a preemptive renegotiation offer: they can expect to receive the (high) recovery rates negotiated in a preemptive agreement, even though these are less than $100 \%$. Alternatively, they can reject the preemptive restructuring proposal and face uncertain returns, since the debtor pays in full in some income states, but it defaults and repays fractionally in other income states. Our model predicts that preemptive renegotiation will occur only if the risk

\footnotetext{
${ }^{13}$ The coefficients are smaller in size for post-default restructurings, also because these episodes are very protracted and because some sovereigns manage to issue external debt before the finalization of restructurings. Nevertheless, the probability of access remains close to zero.
} 
of default is high, meaning that a (costly) default seems likely. Otherwise the country and creditors will prefer to wait and do nothing, in the expectation that a default is avoided.

The second purpose of the model is to explain why preemptive renegotiations involve lower haircuts and are shorter (including a shorter period of market exclusion). We endogenize these two features in our model, with a simple intuition behind:

- Haircuts are lower in preemptive deals because the offer is made ex-ante, before income is realized and before a potential default. Creditors will only agree to a preemptive exchange if the value of the new bonds offered to them is at least as high as the value of the old bonds, i.e., their expected return accounting for the risk of a default later on. Put differently, the recovery rate must be attractive enough, otherwise creditors will reject and hope that their debt is serviced in full (in case the output shock is not bad). There is no such outside option in post-default renegotiations. In default, a haircut is unavoidable and accepting an exchange offer is the only option for creditors to receive any payments on the defaulted debt. As a result, creditors will agree to higher average haircuts in default.

- The duration of preemptive deals is shorter because the output cost in this type of renegotiation is lower and because no payments are missed (no arrears accumulate). The recovery in preemptive cases will therefore be quicker, so that the country is more likely to reach an output level that allows an exchange to take place. This rationale follows Benjamin and Wright (2009) and Bi (2008) who show that both the sovereign and the creditors can have an incentive to "wait for a larger cake" before debt settlements. In post-default cases, the higher economic costs undermine the country's repayment capacity in each period. This lowers the probability of resuming payments and exiting the crisis, resulting in longer delay.

\subsection{Basic Framework}

Our model deals with sovereign default and renegotiation in the tradition of Eaton and Gersovitz (1981). The country is risk averse and cannot affect world risk-free interest rate. The country's preference is defined by the following utility function:

$$
E_{0} \sum_{t=0}^{\infty} \beta^{t} u\left(c_{t}\right)
$$

where $0<\beta<1$ is a discount factor, $c_{t}$ denotes consumption in period $t$ and $u($.$) is its$ one-period utility function, which is continuous, strictly increasing, and strictly concave and satisfies the Inada conditions. The discount rate reflects both pure time preference and the probability that the current sovereignty remains the same in the next period.

In each period, the country receives an exogenous, stochastic income shock $y_{t}$, which is drawn from a compact set $Y=\left[y_{\text {min }}, y_{\text {max }}\right] \subset \mathbb{R}_{+} \cdot \mu\left(y_{t+1} \mid y_{t}\right)$ is the probability distribution of a shock $y_{t+1}$ conditional on the previous realization $y_{t}$. In addition, the country has a 
credit record $h_{t} \in[0,1,2]$ which indicates whether the country has maintained access to capital market $\left(h_{t}=0\right)$, or whether it has lost access due to a preemptive restructuring $\left(h_{t}=1\right)$, or due to a default/post-default restructuring $\left(h_{t}=2\right)$. This notation on the country's credit record keeps track of where we are in the bargaining game, in particular the differences in costs and arrears accumulation between post-default and preemptive processes. The information on the country's assets, credit record, and income shock is symmetric and perfect for both the country and its creditors. ${ }^{14}$

Foreign creditors are risk-neutral and they can borrow or lend as much as needed at a constant risk-free interest rate in the international capital market.

The international capital market is incomplete. The country and foreign investors can borrow and lend only via one-period zero-coupon bonds where $b_{t+1}$ denotes the amount of bonds to be repaid next period. ${ }^{15} 16$ When the country purchases bonds, $b_{t+1}>0$, and when it issues new bonds, $b_{t+1}<0$. The set of amount of bonds is $B=\left[b_{\min }, \infty\right) \subset \mathbb{R}$ where $b_{\min } \leq 0$. The lower bound is the highest level of debt that the country can hold, i.e., $b_{\min }<-y^{\max } / r^{*}$ as in Arellano (2008) and Chatterjee and Eyigungor (2012). We assume $q\left(b_{t+1}, h_{t}, y_{t}\right)$ is the price of a bond with asset position $\left(b_{t+1}\right)$, credit record $\left(h_{t}\right)$, and income level $\left(y_{t}\right)$. The bond price will be determined in equilibrium.

We assume that creditors always commit to repay their debt. However, the sovereign is free to decide whether to repay its debt or to default. If the sovereign chooses to repay its debt, it will preserve access to the international capital market in the next period $\left(h_{t+1}=0\right)$. If the sovereign chooses to default, it is subject to exclusion from the international capital market, direct output cost $\left(\lambda_{d} y_{t}\right)$ and accumulation of arrears. ${ }^{17}$ In case of a preemptive restructuring and no default, the country will still be excluded from the international capital market during the renegotiation process but it suffers smaller output costs $\left(\lambda_{p} y_{t}\right)$ and does not accumulate arrears. This important assumption of output costs is consistent with the empirical analysis in Section 3, which shows that output losses during preemptive restructurings are significantly lower than in crises with a unilateral default.

Like in reality, a sovereign can initiate debt renegotiations at two points in time: (i) preemptively, i.e., before observing current income and prior to a potential default, or (ii) post-default, after income is realized and the sovereign finds defaulting optimal.

Preemptive restructurings will be initiated immediately after the sovereign's choice (ex-

\footnotetext{
${ }^{14}$ Our model does not assume any ex-ante information asymmetries or disincentives of the debtor that make a default unavoidable.

${ }^{15}$ We use a conventional debt restructuring model with one-period zero-coupon bonds as in Benjamin and Wright (2009), Bi (2008), and Yue (2010). Some recent studies use models with long maturity bonds without restructurings, for instance Hatchondo and Martinez (2009), Chatterjee and Eyigungor (2012), and Arellano and Ramanarayanan (2012).

${ }^{16}$ Introducing coupons makes a default and a preemptive restructuring relatively more attractive compared to repaying. The repayment region will shrink, while the default and preemptive renegotiation regions will increase (the default region even more so). Nevertheless, the shift to coupon bonds is unlikely to change our results qualitatively or quantitatively, since coupon payments only account for a small fraction of total payments in our model with one-period zero-coupon bonds.

${ }^{17}$ Mendoza and Yue (2012) provide micro-foundations for this assumption. In their model defaulting is costly since it implies exclusion from credit markets, which leads to losses in production efficiency due to a lack of imported inputs and labor reallocation away from final goods production.
} 
ante) and before the realization of current income. After the announcement of a preemptive restructuring, the sovereign will lose access until it restructures its bonds $\left(h_{t+1}=1\right)$ and suffers (lower) output costs. The recovery rates are determined by both parties taking into account expected current income. In post-default cases, the sovereign will be in financial autarky until the restructuring $\left(h_{t+1}=2\right)$ and faces (higher) output costs $\left(\lambda_{d} y_{t}\right)$. In order to avoid permanent exclusion from capital markets and a continuous loss of output, the country always has an incentive to renegotiate and to repay the defaulted debt to exit the crisis. The recovery rates on this debt will be driven by the expectations of next-period income, but settled after the current income realization.

Also creditors have an incentive to renegotiate over debt reduction after default, since renegotiation is the only option to recoup losses on the debt in arrears. Creditors will agree to preemptive renegotiations if the recovery rates proposed in the negotiations are at least higher than the expected return on bonds accounting for the probability of either full repayment and/or for the recovery rates conditional on default. Otherwise, they will reject the offer.

For both restructuring cases, the parties decide whether to conclude the negotiation process and exchange the debt after observing realized income $\left(y_{t+1}\right)$. In case of a restructuring, the country resumes access to the financial market in the next period $\left(h_{t+2}=0\right)$. This implies that the country can issue new debt in order to repay the recovered debt to creditors (old debt * recovery rates). If the sovereign does not restructure, it will remain in autarky and the debt exchange is postponed to a future period $\left(h_{t+2}=1\right.$ or 2).

Timing of the Model: The timing of decisions in each period is summarized in Figure 4 and can be described as follows:

1. The sovereign starts with initial debt $\left(b_{t}\right)$ and previous income $\left(y_{t-1}\right)$. We are in node $(\mathrm{A})$.

2. The sovereign decides whether to initiate a preemptive debt restructuring or not.

(i) If the country prefers to restructure its debt preemptively, we move to the upper branch of the tree and are in node $(\mathrm{B})$. At preemptive renegotiation, both the country and creditors decide over recovery rates $\delta\left(b_{t}, 0, y_{t-1}\right)$.

(ii) If the country chooses not to take the preemptive option, we move to the lower branch of the tree and are in node $(\mathrm{C})$.

3. Income $y_{t}$ realizes.

4. (i) In node (B) (preemptive route), the country suffers output costs $\left(\lambda_{p} y_{t}\right)$ and loses access to the market $\left(h_{t+1}=1\right)$ after the realization of income $y_{t}$.

(ii) In node (C) (on the lower branch of the tree), the country decides whether to pay its debt or to default after observing its income. 
5. If default is chosen, we move to the middle branch of the tree. At post-default renegotiation, the country and creditors choose recovery rates $\alpha\left(b_{t}, 0, y_{t}\right)$ on the defaulted debt. The country suffers output costs $\lambda_{d} y_{t}$ and also loses access to the international capital market $\left(h_{t+1}=2\right)$.

6. If the country decides to pay its debt, we proceed to the lower branch of the tree. The country maintains market access $\left(h_{t+1}=0\right)$ and chooses its consumption $\left(c_{t}\right)$ and the level of debt in the next period $\left(b_{t+1}\right)$. Default risk is determined and creditors also choose $b_{t+1}$. The price of bonds is determined in the market. The country will again move to node $(\mathrm{A})$.

7. Income $y_{t+1}$ realizes.

8. (i) In node (D) in period $t+1$ (upper branch of the tree), the country chooses to exchange its debt or not. If it opts to restructure, it regains access to the market next period $\left(h_{t+2}=0\right)$. Otherwise, it remains in financial autarky $\left(h_{t+2}=1\right)$ and the exchange is postponed and negotiations start again (back to node (D)).

(ii) The same logic applies to node (E) in period $\mathrm{t}+1$ (middle branch of the tree). Again, the sovereign chooses to exchange its debt or not. If it decides to restructure, it regains access to the market next period $\left(h_{t+2}=0\right)$. Otherwise, it remains in autarky $\left(h_{t+2}=2\right)$ and the exchange is postponed (back to node $(\mathrm{E})$ ).

Sovereigns have no reason to technically default in node (B) and move to node (C), meaning that they will not breach a preemptive negotiation process which was optimal ex-ante. The reason is that debtors would need a very large incentive to deviate (from B) in order to compensate for the larger expected output costs and longer exclusion (in $\mathrm{C}$ ). Haircuts would need to change significantly, with a large increase in the post-default setting, and a large decrease in the preemptive setting. Effectively, the haircuts in preemptive renegotiations would need to move close to zero, otherwise the deviation incentive will not be large enough. This, however, would make the preemptive restructuring option very unattractive ex-ante, since the costs of preemptive renegotiations (output losses and market exclusion) will exceed the resulting net benefit of debt relief. The deviation from (B) to (C) is therefore off the equilibrium path.

\section{Recursive Equilibrium}

\subsection{Sovereign's Problem}

The sovereign's problem is to maximize expected lifetime utility. First, we consider the case of $h_{t}=0$, thus assuming that the sovereign has maintained access to the capital market. Prior to the realization of its income shock, the sovereign decides whether it initiates a preemptive restructuring or not: 
Figure 4: Timing of the Model

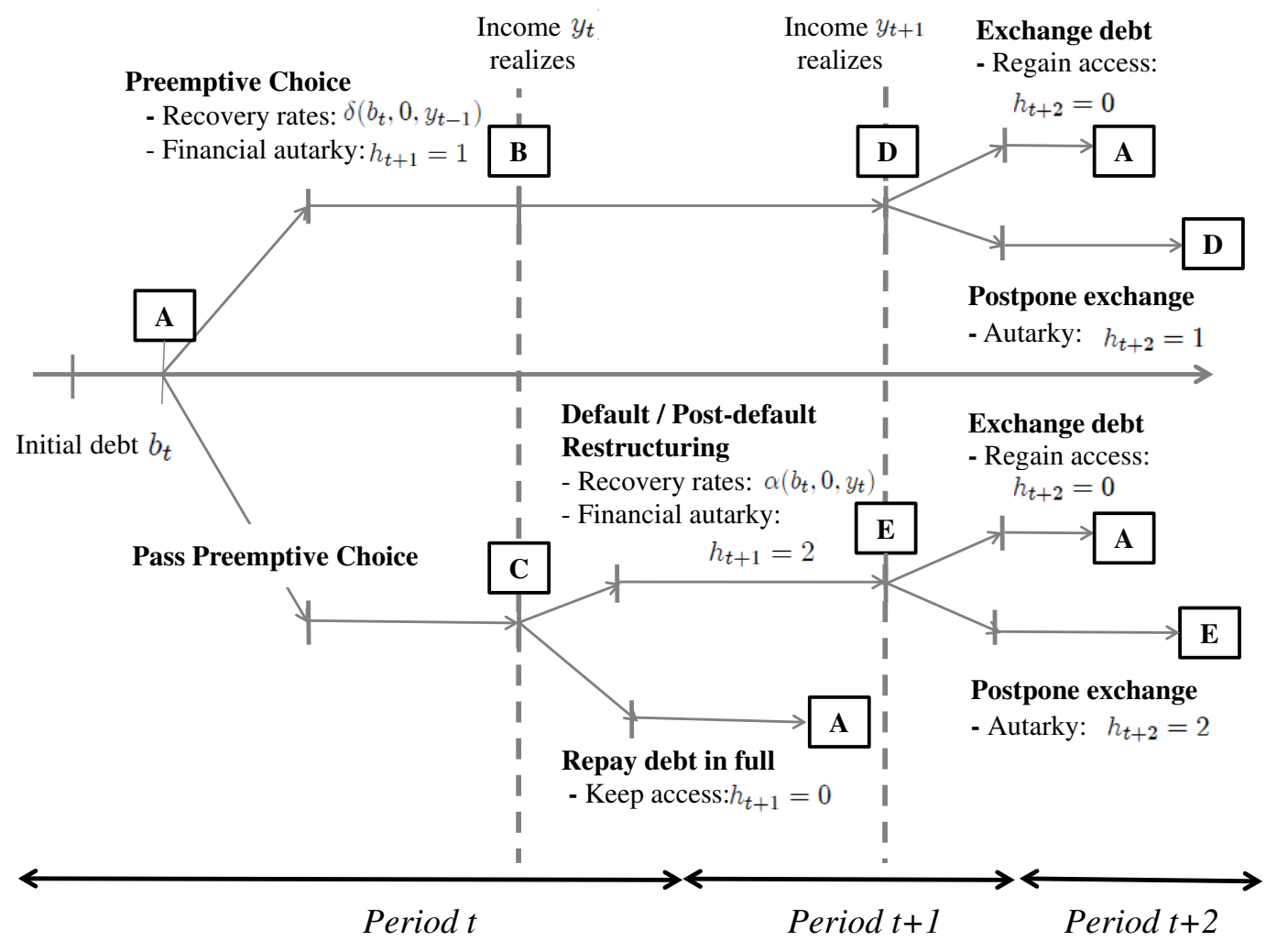

$$
V^{E X A N T E}\left(b_{t}, 0, y_{t-1}\right)=\max \left[V^{P R E}\left(b_{t}, 0, y_{t-1} ; \delta\left(b_{t}, 0, y_{t-1}\right)\right), V^{N O N-P R E}\left(b_{t}, 0, y_{t-1}\right)\right]
$$

where $V^{P R E}\left(b_{t}, 0, y_{t-1} ; \delta\left(b_{t}, 0, y_{t-1}\right)\right)$ is the value of initiating a preemptive restructuring:

$$
V^{P R E}\left(\begin{array}{c}
b_{t}, 0, y_{t-1} ; \\
\delta\left(b_{t}, 0, y_{t-1}\right)
\end{array}\right)=\int_{Y}\left[\begin{array}{c}
u\left(\left(1-\lambda_{p}\right) y_{t}\right) \\
+\beta \int_{Y} V\left(\delta\left(b_{t}, 0, y_{t-1}\right) b_{t}, 1, y_{t+1}\right) d \mu\left(y_{t+1} \mid y_{t}\right)
\end{array}\right] d \mu\left(y_{t} \mid y_{t-1}\right)
$$

The expression $\int_{Y} u\left(\left(1-\lambda_{p}\right) y_{t}\right) d \mu\left(y_{t} \mid y_{t-1}\right)$ represents ex-ante utility from consumption while $V\left(\delta\left(b_{t}, 0, y_{t-1}\right) b_{t}, 1, y_{t+1}\right)$ denotes the value function in the next period with an intermediate credit record $\left(h_{t+1}=1\right)$ and debt $b_{t+1}=\delta\left(b_{t}, 0, y_{t-1}\right) b_{t} . V^{N O N-P R E}\left(b_{t}, 0, y_{t-1}\right)$ is the sovereign's ex-ante value of postponing its preemptive restructuring, which is based on ex-post value $V\left(b_{t}, 0, y_{t}\right)$ as follows:

$$
V^{N O N-P R E}\left(b_{t}, 0, y_{t-1}\right)=\int_{Y} V\left(b_{t}, 0, y_{t}\right) d \mu\left(y_{t} \mid y_{t-1}\right)
$$


We define an indicator of preemptive renegotiation choice;

$$
I\left(b_{t}, 0, y_{t-1}\right)=\left\{\begin{array}{cc}
1 & \text { if } \\
V^{P R E}\left(b_{t}, 0, y_{t-1} ; \delta\left(b_{t}, 0, y_{t-1}\right)\right) \geq V^{N O N-P R E}\left(b_{t}, 0, y_{t-1}\right) \\
0 \text { otherwise }
\end{array}\right\}
$$

Next comes the sovereign's decision after the income shock is realized. The sovereign chooses whether to default or not via

$$
V\left(b_{t}, 0, y_{t}\right)=\max \left[V^{D}\left(b_{t}, 0, y_{t} ; \alpha\left(b_{t}, 0, y_{t}\right)\right), V^{N}\left(b_{t}, 0, y_{t}\right)\right]
$$

where $V^{D}\left(b_{t}, 0, y_{t} ; \alpha\left(b_{t}, 0, y_{t}\right)\right)$ is the sovereign's ex-post value function of defaulting given as:

$$
V^{D}\left(\begin{array}{c}
b_{t}, 0, y_{t} ; \\
\alpha\left(b_{t}, 0, y_{t}\right)
\end{array}\right)=u\left(\left(1-\lambda_{d}\right) y_{t}\right)+\beta \int_{Y} V\left((1+r) \alpha\left(b_{t}, 0, y_{t}\right) b_{t}, 2, y_{t+1}\right) d \mu\left(y_{t+1} \mid y_{t}\right)
$$

where $b_{t+1}=(1+r) \alpha\left(b_{t}, 0, y_{t}\right) b_{t}$.

$V^{N}\left(b_{t}, 0, y_{t}\right)$ is the sovereign's value function with repayment or savings. After receiving savings $\left(b_{t} \geq 0\right)$ or paying debt $\left(b_{t}<0\right)$, the sovereign chooses current consumption $c_{t}$ and next-period assets (debt) $b_{t+1}$ given the bond price $q\left(b_{t+1}, 0, y_{t}\right)$, so that

$$
\begin{gathered}
V^{N}\left(b_{t}, 0, y_{t}\right)=\max _{c_{t}, b_{t+1}} u\left(c_{t}\right)+\beta \int_{Y} V\left(b_{t+1}, 0, y_{t+1}\right) d \mu\left(y_{t+1} \mid y_{t}\right) \\
\text { s.t. } \quad c_{t}+q\left(b_{t+1}, 0, y_{t}\right) b_{t+1}=y_{t}+b_{t}
\end{gathered}
$$

The country's default policy can be characterized by $D\left(b_{t}, 0\right) \subset Y$, defined as the set of income shocks for which default is optimal:

$$
D\left(b_{t}, 0\right)=\left\{y_{t} \in Y: V^{N}\left(b_{t}, 0, y_{t}\right)<V^{D}\left(b_{t}, 0, y_{t} ; \alpha\left(b_{t}, 0, y_{t}\right)\right)\right\}
$$

We now consider the sovereign's problem with an intermediate credit record $h_{t}=1$ where the country has already initiated the preemptive restructuring process, but has not exchanged its debt yet. It is still excluded from the market and suffers the output costs associated with preemptive renegotiations $\left(\lambda_{p} y_{t}\right)$. After observing realized income, the country decides whether to restructure in the current period or to postpone the exchange.

$$
V\left(b_{t}, 1, y_{t}\right)=\max \left[V^{E}\left(b_{t}, 1, y_{t}\right), V^{D}\left(b_{t}, 1, y_{t}\right)\right]
$$

where $V^{E}\left(b_{t}, 1, y_{t}\right)$ is the value associated with a debt exchange shown as

$$
\begin{gathered}
V^{E}\left(b_{t}, 1, y_{t}\right)=u\left(c_{t}\right)+\beta \int_{Y} V\left(b_{t+1}, 0, y_{t+1}\right) d \mu\left(y_{t+1} \mid y_{t}\right) \\
\text { s.t. } \quad c_{t}+q\left(b_{t+1}, 0, y_{t}\right) b_{t+1}=\left(1-\lambda_{p}\right) y_{t}+b_{t}
\end{gathered}
$$


while $V^{D}\left(b_{t}, 1, y_{t}\right)$ is the value of postponing the exchange to later periods shown as

$$
V^{D}\left(b_{t}, 1, y_{t}\right)=u\left(\left(1-\lambda_{p}\right) y_{t}\right)+\beta \int_{Y} V\left(b_{t}, 1, y_{t+1}\right) d \mu\left(y_{t+1} \mid y_{t}\right)
$$

where $b_{t+1}=b_{t}$ assumes that the sovereign does not accumulate arrears. The sovereign opts to delay the exchange if its realized income is lower than that expected at the settlement of renegotiation.

Lastly, we solve the sovereign's problem with a bad credit record $\left(h_{t}=2\right)$ which implies that it defaulted and initiated post-default debt renegotiations, but has not exchanged its debt yet. The country suffers high output costs $\left(\lambda_{d} y_{t}\right)$ and remains in financial autarky. After observing its realized income, it decides whether to exchange its debt in the current period or to postpone the exchange to a subsequent period:

$$
V\left(b_{t}, 2, y_{t}\right)=\max \left[V^{E}\left(b_{t}, 2, y_{t}\right), V^{D}\left(b_{t}, 2, y_{t}\right)\right]
$$

where $V^{E}\left(b_{t}, 2, y_{t}\right)$ is the value of exchanging debt shown as

$$
\begin{gathered}
V^{E}\left(b_{t}, 2, y_{t}\right)=u\left(c_{t}\right)+\beta \int_{Y} V\left(b_{t+1}, 0, y_{t+1}\right) d \mu\left(y_{t+1} \mid y_{t}\right) \\
\text { s.t. } \quad c_{t}+q\left(b_{t+1}, 0, y_{t}\right) b_{t+1}=\left(1-\lambda_{d}\right) y_{t}+b_{t}
\end{gathered}
$$

while $V^{D}\left(b_{t}, 2, y_{t}\right)$ is the value of postponing the exchange shown as

$$
V^{D}\left(b_{t}, 2, y_{t}\right)=u\left(\left(1-\lambda_{d}\right) y_{t}\right)+\beta \int_{Y} V\left((1+r) b_{t}, 2, y_{t+1}\right) d \mu\left(y_{t+1} \mid y_{t}\right)
$$

where $b_{t+1}=(1+r) b_{t}$ assumes that the sovereign accumulates arrears. As in the case with an intermediate credit record, the sovereign opts to delay the exchange if its realized income is lower than that expected at settlement.

The country's debt exchange choice can be characterized by exchange set $E\left(b_{t}, h_{t}\right) \subset Y$ for $h_{t}=1$, or 2 . It is a set of income shocks for which exchange is optimal.

$$
E\left(b_{t}, i\right)=\left\{y_{t} \in Y: V^{E}\left(b_{t}, i, y_{t}\right) \geq V^{D}\left(b_{t}, i, y_{t}\right)\right\} \quad \text { for } \quad i=1,2
$$

\subsection{Debt Renegotiation Problem}

Both preemptive and post-default restructurings take the form of a generalized Nash bargaining game in which the recovery rates on unpaid debt are optimally chosen by the two parties. To allow preemptive and post-default restructurings to occur at different points in time (ex-ante and ex-post) we assume a one-round bargaining game for each restructuring. This keeps the model tractable while maintaining the key elements of the bargaining game. Extending our model to a multi-round setting would have few additional 
benefits for our purposes, but would make it challenging to differentiate preemptive from post-default renegotiations. ${ }^{18}$

We start with the post-default restructuring case and assume that renegotiation only takes place once after each default event. The threat point of this bargaining game is that the sovereign is excluded from the market permanently and creditors receive nothing on the defaulted debt. In post-default renegotiations, both parties agree on the recovery rates $\alpha\left(b_{t}, 0, y_{t}\right)$ and the utility value of the sovereign is shown as

$$
V^{D}\left(b_{t}, 0, y_{t} ; \alpha\left(b_{t}, 0, y_{t}\right)\right)=u\left(\left(1-\lambda_{d}\right) y_{t}\right)+\beta \int_{Y} V\left((1+r) \alpha\left(b_{t}, 0, y_{t}\right) b_{t}, 2, y_{t+1}\right) d \mu\left(y_{t+1} \mid y_{t}\right)
$$

During default, the sovereign suffers from output losses $\left(\lambda_{d} y_{t}\right)$ and is excluded from the international capital market. It can not issue any new debt and simply rolls over the defaulted debt as arrears. Its value of autarky can thus be written as:

$$
V^{A U T}\left(y_{t}\right)=u\left(\left(1-\lambda_{d}\right) y_{t}\right)+\beta \int_{Y} V^{A U T}\left(y_{t+1}\right) d \mu\left(y_{t+1} \mid y_{t}\right)
$$

For any debt recovery rate $a_{t}$, we denote the sovereign's surplus in Nash bargaining by $\Psi^{B}\left(a_{t} ; b_{t}, 0, y_{t}\right)$, which is the difference between the value of accepting the proposed recovery rate $a_{t}$ and the value of rejecting it, given the sovereign's assets (debt) $b_{t}$, credit record $h_{t}=0$, and an income shock $y_{t}$ :

$$
\Psi^{B}\left(a_{t} ; b_{t}, 0, y_{t}\right)=V^{D}\left(b_{t}, 0, y_{t} ; \alpha\left(b_{t}, 0, y_{t}\right)\right)-V^{A U T}\left(y_{t}\right)
$$

The cost of exiting default is that the sovereign needs to repay the restructured debt, while the benefit (surplus) comes from reaccessing financial markets and avoiding the output costs of default in subsequent periods. Equation (17) clearly shows that the option of proceeding to a post-default restructuring is preferable to being in financial autarky permanently. After the sovereign repays the restructured debt to creditors at the time of the debt exchange, it will be able to issue new bonds. This is akin to an exchange of old bonds for new bonds at a haircut, as observed in many actual restructurings.

The surplus to foreign creditors is the present value of the recovered debt:

$$
\Psi^{L}\left(a_{t} ; b_{t}, 0, y_{t}\right)=a_{t}\left(-b_{t}\right)
$$

where there is no outside option for creditors at a post-default restructuring.

We assume that the sovereign has a bargaining power $\theta$ and foreign creditors have a

\footnotetext{
${ }^{18}$ Benjamin and Wright (2009) and Bi (2008) study multi-round debt renegotiations for sovereigns. While Benjamin and Wright (2009) assume that the debtor and a representative creditor randomly alternate their ability to propose an offer, Bi (2008) assumes that lenders have an option to "pass" proposing to the debtor. In the context of our model, the main benefit of a multi-round setting would be a better replication of (longer) delays and (higher) debt levels. But this comes at the cost of making it much harder to solve the model (see also D'Erasmo (2010) and Asonuma and Joo (2014)).
} 
bargaining power $(1-\theta)$, where $\theta$ summarizes the institutional arrangement of sovereign debt restructurings. To ensure that the bargaining problem is well specified, we define the bargaining power set $\Theta \subset[0,1]$ such that $\theta \in \Theta$, the overall negotiation surplus, has a unique optimum.

Given the country's debt level $b_{t}<0$, credit record $h_{t}=0$, and income shock $y_{t}$, we can solve the following bargaining problem on the post-default recovery rates $\alpha\left(b_{t}, 0, y_{t}\right)$ :

$$
\begin{aligned}
\alpha\left(b_{t}, 0, y_{t}\right)=\arg \max & {\left[\left(\Psi^{B}\left(a_{t} ; b_{t}, 0, y_{t}\right)\right)^{\theta}\left(\Psi^{L}\left(a_{t} ; b_{t}, 0, y_{t}\right)\right)^{1-\theta}\right] } \\
\text { s.t. } & \Psi^{B}\left(a_{t} ; b_{t}, 0, y_{t}\right) \geq 0 \\
\text { s.t. } & \Psi^{L}\left(a_{t} ; b_{t}, 0, y_{t}\right) \geq 0
\end{aligned}
$$

where $\alpha($.$) are optimal recovery rates and a_{t}$ are general (non-optimal) ones. The defaulting debtor benefits from agreeing to a post-default debt exchange, which yields better or at least equal outcomes compared to remaining in financial autarky (through its participation constraint). Similarly, creditors have an incentive to agree to a post-default restructuring, since the outcome is better or at least equal to remaining in default and receiving nothing on the defaulted debt (through their participation constraint).

Next, we move on to consider preemptive renegotiations, supposing that the sovereign chooses this option. Contrary to post-default cases, the threat point of a preemptive bargaining game is that foreign creditors can potentially be paid in full and that no restructuring can occur. The value of the outside option for both parties therefore clearly differs from those in post-default restructuring, where creditors have no choice but to accept a (higher) haircut:

$$
V^{P R E}\left(\begin{array}{c}
b_{t}, 0, y_{t-1} ; \\
\delta\left(b_{t}, 0, y_{t-1}\right)
\end{array}\right)=\int_{Y}\left[\begin{array}{c}
u\left(\left(1-\lambda_{p}\right) y_{t}\right) \\
+\beta \int_{Y} V\left(\delta\left(b_{t}, 0, y_{t-1}\right) b_{t}, 1, y_{t+1}\right) d \mu\left(y_{t+1} \mid y_{t}\right)
\end{array}\right] d \mu\left(y_{t} \mid y_{t-1}\right)
$$

$V^{N O N-P R E}\left(b_{t}, 0, y_{t-1}\right)$ is the ex-ante value of the country choosing not to initiate a preemptive restructuring, written as

$$
V^{N O N-P R E}\left(b_{t}, 0, y_{t-1}\right)=\int_{Y} V\left(b_{t}, 0, y_{t}\right) d \mu\left(y_{t} \mid y_{t-1}\right)
$$

For any debt recovery rate $a_{t}^{P}$, we denote the sovereign's surplus at preemptive renegotiation by $\Delta^{B}\left(a_{t}^{P} ; b_{t}, 0, y_{t-1}\right)$, which is the difference between the value of accepting the proposed recovery rate $a_{t}^{P}$ and the value of rejecting the offer:

$$
\Delta^{B}\left(a_{t}^{P} ; b_{t}, 0, y_{t-1}\right)=V^{P R E}\left(b_{t}, 0, y_{t-1} ; \delta\left(b_{t}, 0, y_{t-1}\right)\right)-V^{N O N-P R E}\left(b_{t}, 0, y_{t-1}\right)
$$

The sovereign's surplus comes from two sources: it benefits from the lower output costs 
and the potentially shorter duration of financial autarky compared to post-default cases, but it achieves less debt relief (lower haircuts) and therefore has to pay more after the negotiations. In contrast, the surplus to investors is the difference between the present value of the (high) recovered debt payment and the expected return on bonds without a preemptive exchange, accounting for the possibility of default and high haircuts later on. The creditors' surplus can thus be shown as

$$
\Delta^{L}\left(a_{t}^{P} ; b_{t}, 0, y_{t-1}\right)=a_{t}^{P}\left(-b_{t}\right)-\left[1-p\left(b_{t}, 0, y_{t-1}\right)+p\left(b_{t}, 0, y_{t-1}\right) \gamma\left(b_{t}, 0, y_{t-1}\right)\right]\left(-b_{t}\right)
$$

Given the country's debt $b_{t}$, credit record $\left(h_{t}=0\right)$, and previous income shock $y_{t-1}$, we can solve the following bargaining problem on the recovery rates in preemptive restructurings:

$$
\begin{aligned}
\delta\left(b_{t}, 0, y_{t-1}\right)=\arg \max & {\left[\left(\Delta^{B}\left(a_{t}^{P} ; b_{t}, 0, y_{t-1}\right)\right)^{\theta}\left(\Delta^{L}\left(a_{t}^{P} ; b_{t}, 0, y_{t-1}\right)\right)^{1-\theta}\right] } \\
\text { s.t. } & \Delta^{B}\left(a_{t}^{P} ; b_{t}, 0, y_{t-1}\right) \geq 0 \\
\text { s.t. } & \Delta^{L}\left(a_{t}^{P} ; b_{t}, 0, y_{t-1}\right) \geq 0
\end{aligned}
$$

The bargaining power of both parties is assumed to be symmetric, i.e. distributed in the same way in both types of restructurings. Endogenously, however, the model will generate creditor bargaining power to be stronger in preemptive renegotiations than in post-default cases (and sovereign bargaining power to be lower). This is because creditors in preemptive negotiations always have the outside option of rejecting the offer and potentially receiving full repayment, which is an option that does not exist in the post-default setting. ${ }^{19}$

\subsection{Foreign Investors' Problem}

When the sovereign's credit record is good $\left(h_{t}=0\right)$, foreign creditors choose the amount of assets $\left(b_{t+1}\right)$ to maximize their expected profits from bond investments $\pi\left(b_{t+1}, 0, y_{t}\right)$, such that

$\pi\left(b_{t+1}, 0, y_{t}\right)=\left\{\begin{array}{c}q\left(b_{t+1}, 0 . y_{t}\right) b_{t+1}-\frac{1}{1+r} b_{t+1} \quad \text { if } \quad b_{t+1} \geq 0 \\ \frac{\delta\left(b_{t+1}, 0, y_{t}\right)}{1+r}\left(-b_{t+1}\right)-q\left(b_{t+1}, 0 . y_{t}\right)\left(-b_{t+1}\right) \quad \text { if } \quad b_{t+1}<0 \& \quad I\left(b_{t+1}, 0, y_{t}\right)=1 \\ \frac{\left[1-p\left(b_{t+1}, 0, y_{t}\right)+p\left(b_{t+1}, 0, y_{t}\right) \gamma\left(b_{t+1}, 0, y_{t}\right)\right]}{1+r}\left(-b_{t+1}\right)-q\left(b_{t+1}, 0 . y_{t}\right)\left(-b_{t+1}\right) \quad \text { otherwise }\end{array}\right\}$

where $r$ is the risk-free rate and $p\left(b_{t+1}, 0, y_{t}\right)$ is the expected probability of default for the country with debt position $b_{t+1}<0$, credit record, and an income shock $y_{t}$.

Since we assume that the market for new sovereign bonds is perfectly competitive, foreign investors' expected profit is zero in equilibrium. Using a zero expected profit

\footnotetext{
${ }^{19}$ In addition, we assessed the impact of an exogenous increase in creditor bargaining power for preemptive negotiations, thus allowing asymmetric bargaining power across types of renegotiation. The quantitative results changed only marginally.
} 
condition, we get

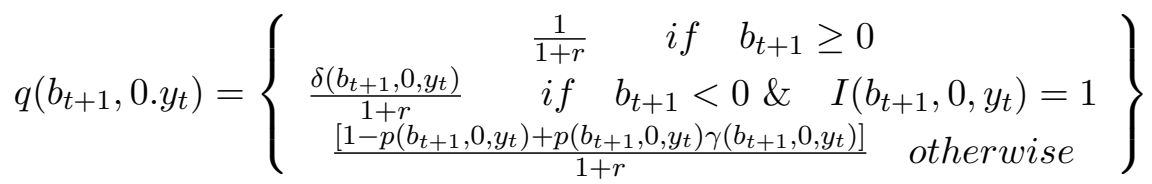

When the sovereign buys bonds from foreign investors $b_{t+1} \geq 0$, its bond price is equal to the price of a risk-free bond $\frac{1}{1+r}$. When the sovereign sells bonds to foreign investors $b_{t+1}<0$, creditors face the risk of a default and post-default restructuring and the risk of a preemptive restructuring with no default but a haircut equivalent to 1 minus the recovery rate $\delta\left(b_{t+1}, 0, y_{t}\right)$. The sovereign bond is priced to compensate creditors for these two types of risks. Since $0 \leq \gamma\left(b_{t+1}, 0, y_{t}\right) \leq 1$ and $0 \leq \delta\left(b_{t+1}, 0, y_{t}\right) \leq 1$, the bond price $q\left(b_{t+1}, 0 . y_{t}\right)$ lies in $\left[0, \frac{1}{1+r}\right]$. The difference between the country's interest rate and the risk-free rate is the sovereign's total spread, defined as:

$$
s\left(b_{t+1}, 0 . y_{t}\right)=\frac{1}{q\left(b_{t+1}, 0 . y_{t}\right)}-(1+r)
$$

\subsection{Recursive Equilibrium of the Model}

We define a recursive equilibrium of the model as a set of functions for, (a) the sovereign's ex-ante and ex-post value functions, asset position, consumption, default set, preemptive restructuring choice, exchange choice set, (b) the two sets of recovery rates $\left(\delta^{*}\left(b_{t}, 0, y_{t-1}\right)\right.$ for preemptive and $\alpha^{*}\left(b_{t}, 0, y_{t}\right)$ for post-default), and (c) the bond price and spreads such that

1. the country's ex-ante value function, ex-post value function, asset position, consumption, default set, preemptive restructuring choice, and its exchange choice set satisfy its optimization problem (1)-(15).

2. the two sets of recovery rates solve the preemptive and post-default renegotiation problems (19) and (23).

3. the bond price function and total spread satisfy the optimal conditions for creditors' problem (25) and (26).

In equilibrium, the default probability $p^{*}\left(b_{t+1}, 0, y_{t}\right)$ is defined by using the country's default decision:

$$
p^{*}\left(b_{t+1}, 0, y_{t}\right)=\int_{D^{*}\left(b_{t+1}, 0\right)} d \mu\left(y_{t+1} \mid y_{t}\right)
$$


The expected recovery rate $\gamma^{*}\left(b_{t+1}, 0, y_{t}\right)$ in equilibrium is computed by using the negotiated recovery rates in the next period $\alpha^{*}\left(b_{t+1}, 0, y_{t+1}\right)$ :

$$
\begin{aligned}
\gamma^{*}\left(b_{t+1}, 0, y_{t}\right) & =\frac{\int_{D^{*}\left(b_{t+1}, 0\right)} \alpha^{*}\left(b_{t+1}, 0, y_{t+1}\right) d \mu\left(y_{t+1}, y_{t}\right)}{\int_{D^{*}\left(b_{t+1}, 0\right)} d \mu\left(y_{t+1}, y_{t}\right)} \\
& =\frac{\int_{D^{*}\left(b_{t+1}, 0\right)} \alpha^{*}\left(b_{t+1}, 0, y_{t+1}\right) d \mu\left(y_{t+1}, y_{t}\right)}{p^{*}\left(b_{t+1}, 0, y_{t}\right)}
\end{aligned}
$$

\section{Quantitative Analysis}

The theoretical model is solved numerically with three main findings. First, we predict the sovereign's choice of preemptive restructuring, default and repayment at the steady-state distribution of the model. We find that governments with a high risk of defaulting are more likely to initiate a preemptive restructuring. Second, the model explores why preemptive restructurings have lower haircuts (higher recovery rates) and shorter duration, as observed in the data. Lastly, our simulation exercise successfully replicates business cycle and non-business cycle moments that match the data of two recent cases, Argentina (2001-2005, post-default) and Uruguay (2003, preemptive).

\subsection{Parameters and Functional Forms}

To facilitate a comparison of results, our benchmark parameter values and the functional forms of the model closely follow established previous work. One important exception is the assumption of low(er) output costs of preemptive restructurings, which is newly introduced in this paper.

We define each period as a quarter. The following constant relative risk-aversion (CRRA) utility functions are used for the sovereign:

$$
u\left(c_{t}\right)=\frac{c_{t}^{1-\sigma}}{1-\sigma}
$$

where $\sigma$ expresses the degree of risk aversion. We set $\sigma$ equal to 2 , as commonly used in real business cycle analyses for emerging markets. The risk-free rate is equal to $1.7 \%$ as in Arellano (2008).

The output cost during post-default restructuring episodes $\lambda_{d}$ is set at $2 \%$. This assumption is in line with the empirical findings by Sturzenegger (2004) and follows many earlier models featuring symmetric lump-sum output cost of default, e.g. Aguiar and Gopinath (2006), Bi (2008), or Yue (2010). In contrast, the output cost during preemptive restructuring episodes $\lambda_{p}$ is set at $1.5 \%$. The lower parameter value can be justified theoretically, since preemptive debt exchanges do not necessarily imply a legal default and should therefore trigger less "collateral damage". In addition, we back up this parameter assumption empirically in Section 3. 
Following convention (Yue (2010)), we model the output growth rate as an AR(1) process as follows:

$$
\log \left(g_{t}\right)=\left(1-\rho_{g}\right) \log \left(1+\mu_{g}\right)+\rho_{g} \log \left(g_{t-1}\right)+\epsilon_{t}^{g}
$$

where $g_{t}=\frac{y_{t}}{y_{t-1}}$ is the growth rate, $\epsilon_{t}^{g} \sim N\left(0, \sigma_{g}^{2}\right)$ is a growth shock and $\log \left(1+\mu_{g}\right)$ is expected log gross growth rate of the country's endowment. We now set the parameter values for our two cases of interest based on quarterly seasonally adjusted GDP data from the Ministry of Economy and Production in Argentina (MECON) and the Banco Central de Uruguay (Central Bank of Uruguay, CBU). The data are detrended using a HodrickPrescott filter with a smoothing parameter of 1600 . We set $\mu_{g}=0.0093, \sigma_{g}=0.0394$, and $\rho_{g}=0.74$ for our first case, Argentina, which implemented a post-default restructuring in 2005, after 3.5 years (14 quarters) in default. Our second case is Uruguay, which implemented a preemptive debt restructuring in 2003, without any missed payments on its bonds. Here we specify $\mu_{g}=0.0065, \sigma_{g}=0.044$, and $\rho_{g}=0.21$. We approximate these stochastic processes as a discrete Markov chain of 41 equally spaced grids by using the quadrature method in Tauchen (1986).

Since output shocks permanently affect the level of endowment in a non-stationary model economy, we detrend the model by dividing by the lagged endowment level $y_{t-1}$. The detrended counterpart of a variable $x_{t}$ is thus, $\hat{x}_{t}=\frac{x_{t}}{x_{t-1}}$. The equilibrium value function, bond price functions, recovery rates, and interest spreads are all evaluated at detrended values.

Sturzenegger and Zettelmeyer (2006) report that Argentina and Uruguay both experienced 6 restructurings in their history (1820-2004). Moreover, according to Struzenegger and Zettlemeyer (2008) the recovery rate (haircut) in Argentina's 2005 debt restructuring was $25.0 \%(75.0 \%)$, whereas the recovery rate (haircut) in Uruguay's 2003 debt restructuring was $87.1 \%(12.9 \%)$. For Argentina, we specify the sovereign's discount factor $\beta=0.80$ and bargaining power $\theta=0.83$ to obtain the country's average annual default frequency of $3.26 \%$, a recovery rate of $25.0 \%$, and a post-default restructuring choice. For Uruguay, the sovereign's discount factor and barging power are set to $\beta=0.83$ and $\theta=0.57$, respectively, to replicate the average default frequency of $3.26 \%$, a recovery rate of $87.1 \%$, and a preemptive restructuring choice. Appendix F summarizes the model parameters, while our computation algorithm is shown in Appendix G.

\subsection{Numerical Results on Equilibrium Properties}

In this subsection, we cover the equilibrium properties of the model for the case of Argentina. For brevity, the equilibrium properties of Uruguay are shown in Appendix H.

We start with Figure 5, which plots equilibrium recovery rates for varying levels of income and indebtedness. As in previous models of sovereign debt renegotiation, such as Yue (2010), we find recovery rates to increase in asset level and income level. What is new in our context is that the patterns differ markedly between preemptive and post-default 
Figure 5: Equilibrium Recovery Rates

A: Preemptive Restructuring

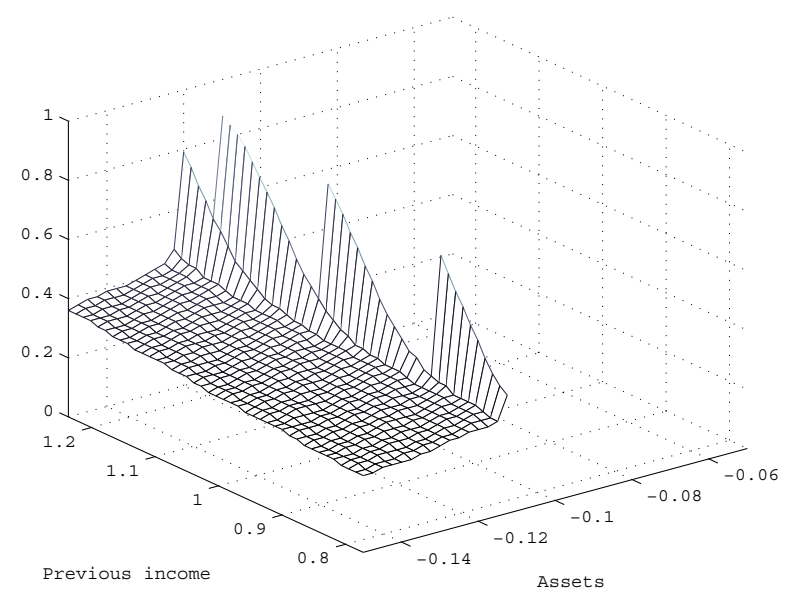

B: Post-default Restructuring

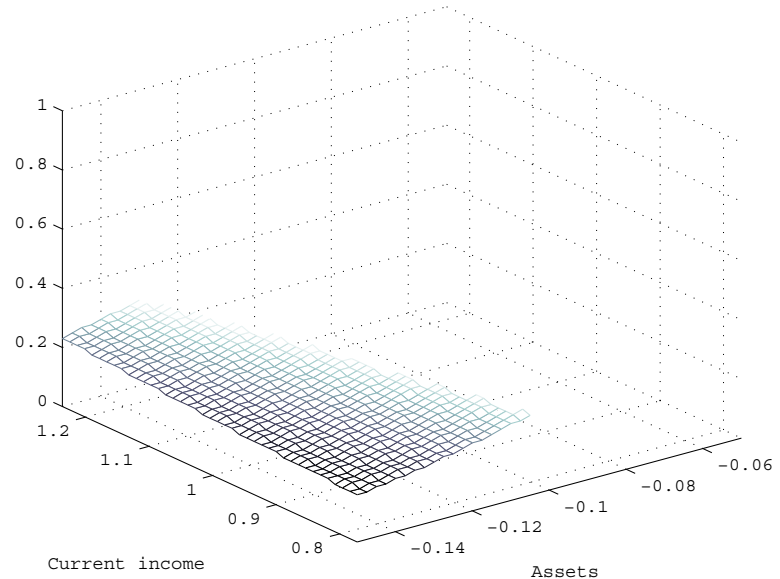

renegotiations (see Panel A and Panel B, respectively). The recovery rates of preemptive restructurings are generally higher than those in post-default cases, given income and debt ratios. This is because creditors demand the recovery rates in preemptive restructurings to be higher than or equal to the expected return of bonds that are not restructured preemptively (and might see a default with high haircuts later on, see equation (22)). Otherwise, creditors will not agree to preemptive debt renegotiations.

We move on to the main trade-offs in the model: the choice for or against a preemptive restructuring, which occurs ex-ante, and the choice of default vs. repayment, which occurs ex-post. Panel A in Figure 6 shows the ex-ante choice for a preemptive restructuring, given the previous income level $y_{t-1}$ and current debt. The sovereign prefers to take the option of a preemptive debt exchange when current debt is high and previous income is low, as 
Figure 6: Equilibrium Choices for Argentina

A: Choice for Preemptive Restr.

(ex-ante)

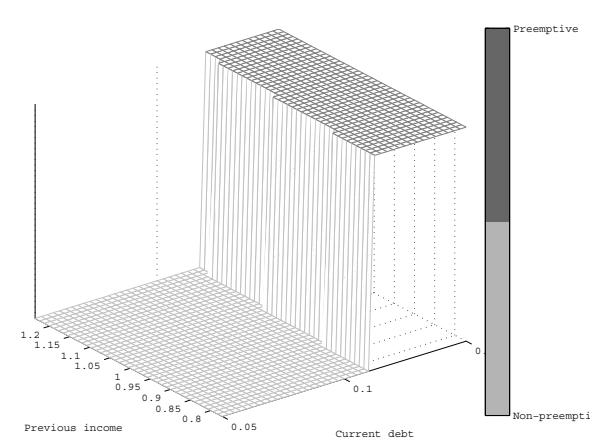

B: Default Choice (ex-post)

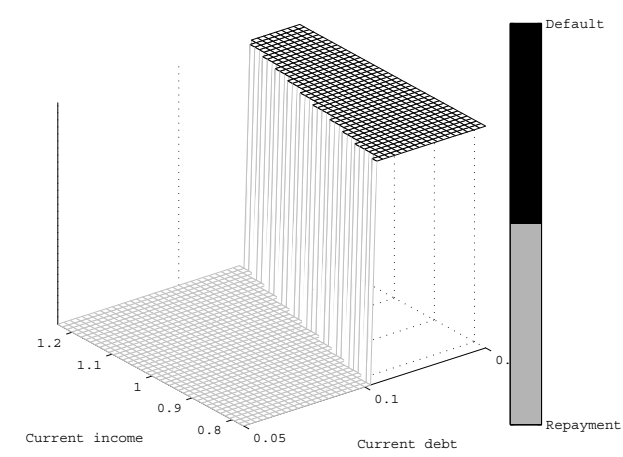

C: Combining the Choice for Preemptive Restructuring, Default and Repayment

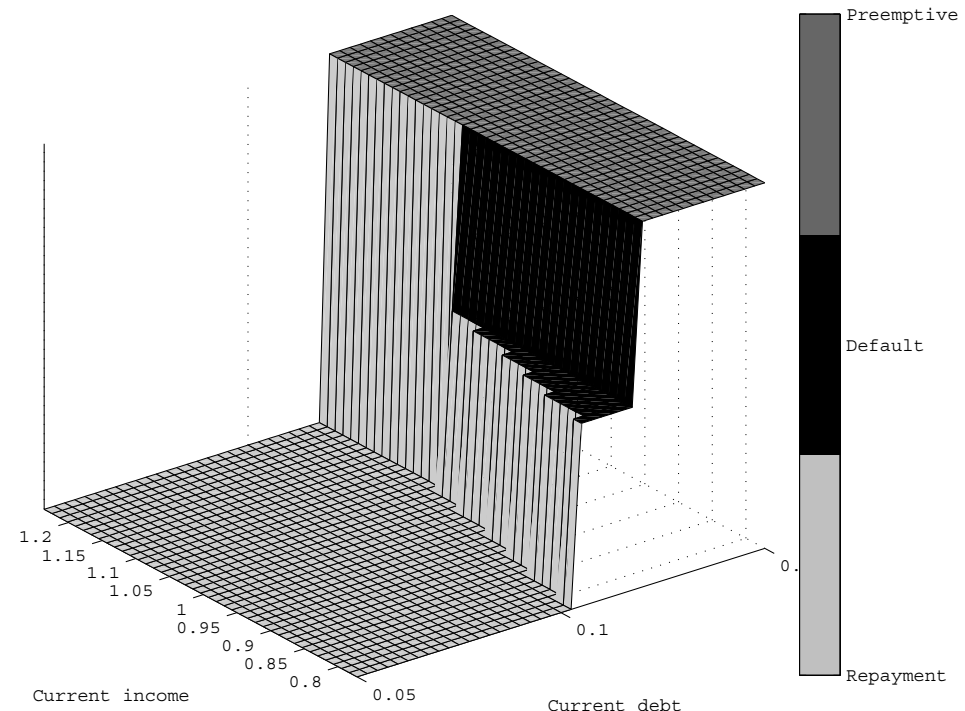

Current debt 
shown in the dark gray region. With a high default probability, it is optimal to renegotiate preemptively and repay a high recovery rate afterwards, instead of defaulting with a high likelihood and suffering from lengthy financial exclusion and costly output losses. When the default probability is low (high previous income and low debt), the sovereign prefers not to initiate renegotiations ex-ante and waits for income to realize, as highlighted in the light gray region. This is because the costs of a preemptive restructuring (short financial exclusion, smaller output loss, and little debt relief) are higher than the expected costs of a default that is unlikely to occur.

Panel B of Figure 6 illustrates the choice between default (post-default restructuring) and repayment, given current income and current debt, i.e. after income has realized. As in previous studies dealing with post-default restructurings, the sovereign chooses to default and renegotiate its debt when current debt is high and current income level is low (the black region), see Yue (2010), Bi (2008), or Asonuma (2012). In the black colored region it is less costly to default and suffer from financial exclusion and output costs compared to paying back in full.

In a next step, in Panel $\mathrm{C}$, we combine the two top panels on the choice for a preemptive restructuring and the choice for default and repayment given mean previous income. The drak gray region corresponds to the ex-ante choice of a preemptive restructuring before observing current income. The region highlighted in black shows the default (and postdefault restructuring) choice taken after the current income realization, while the repayment choice after the income shock is represented by the light gray region. It is clear that the sovereign prefers to take the preemptive restructuring option ex-ante when current debt is higher than a given country-specific threshold ex-post. Conditional on the choice against a preemptive deal, the sovereign then takes the default choice when it receives a bad income shock. Otherwise, it opts to service the current debt in full.

The overall patterns are similar when using data for Uruguay. Importantly, however, we find a smaller probability of default and a higher likelihood of repayment or preemptive debt exchanges given the same levels of debt and income (see Appendix H). This is consistent with our dataset: Uruguay never implemented a post-default restructuring in recent decades (all debt exchanges since 1978 were preemptive), while Argentina mostly had post-default cases (only one restructuring since 1978 was preemptive).

Lastly, we explore the choice for or against a debt exchange at different levels of income and debt for Argentina. This is important to understand our mechanism and why post-default restructurings show longer delays in the model. Figure 7 shows that, in the case of post-default renegotiations, the sovereign chooses to postpone the exchange and, thus, to remain in default when income is low (the black region in Figure 7). At a low income level the sovereign faces a high debt burden to output, also due to the higher output costs and the accumulation of arrears that occur in default. The country therefore prefers to postpone the restructuring until a series of positive income shocks has improved its capacity to repay. In contrast, in preemptive cases, the sovereign opts to exchange its debt at any level of income once the negotiations have been initiated (see Appendix I). This 
is because the country's capacity to repay is less affected by the output costs (which are smaller) and because no arrears accumulate. The sovereign therefore opts to exchange its debt, exits from financial autarky, and no delay longer than 1 period occurs.

Figure 7: The Choice of Exchanging, Postponing or Not Defaulting (Argentina)

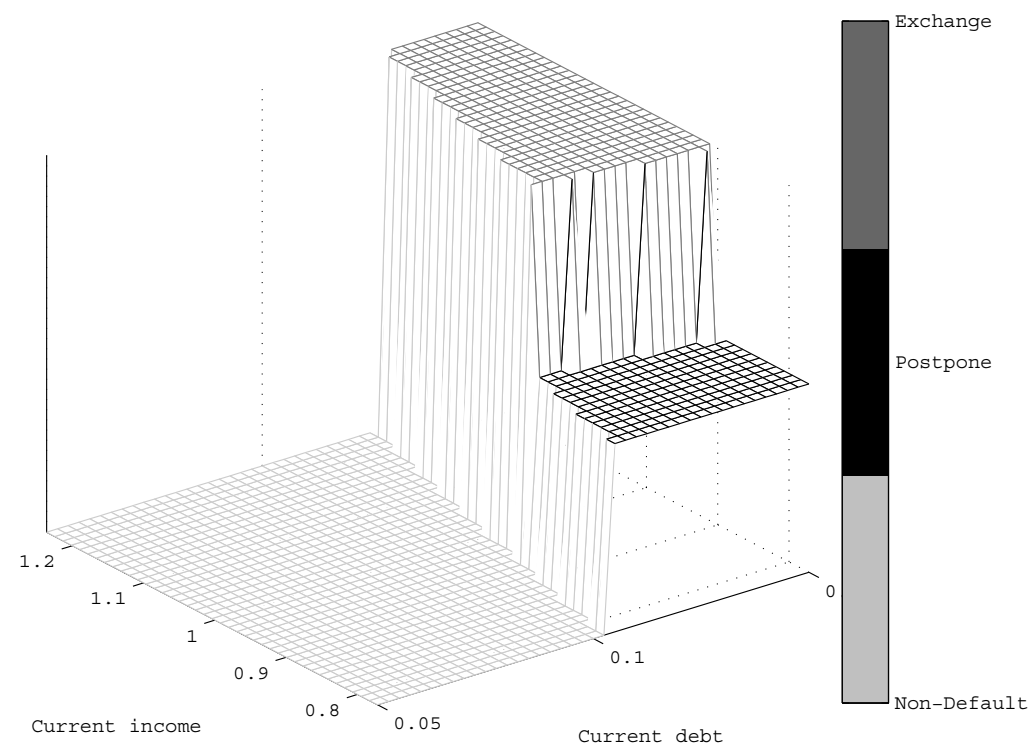

\subsection{Simulation Results}

To see whether the model provides good predictions for the Argentine and Uruguayan restructuring episodes, we conduct 1,000 rounds of simulation with 2,000 periods per round and extract the last 200 observations to evaluate the key features at the steady-state distribution. In the last 200 periods, we pick 40 pre-default observations and observations during the renegotiation spell to compare these with moments in the data for Argentina and Uruguay, respectively. ${ }^{20}$

For a comparison with the data, we use Argentine data from the MECON for 1993Q12001Q4 (before default/renegotiation) and 2002Q1-2005Q2 (during default/renegotiation), where output and trade are quarterly and seasonally adjusted. The trade and output data for Uruguay is taken from the CBU for 1993Q1-2002Q4 (before renegotiation) and 2003Q1-Q2 (during renegotiation). The trade balance is calculated as ratio to GDP. Bond spreads are from the J.P. Morgan Emerging Market Bond Index Global (EMBIG) for both Argentina (1997Q1-2001Q4) and Uruguay (2001Q2-2003Q1). The restructuring duration for Argentina's post-default case was 14 quarters (2001-2005), while Uruguay's preemptive restructuring in 2003 took only 1 quarter to be completed (see Appendix B).

Moreover, we compute two measures of government indebtedness; the first is the average

\footnotetext{
${ }^{20}$ See Arellano (2008) and Yue (2010) for similar simulation procedures.
} 
external debt to GDP ratio from the IMF World Economic Outlook (WEO) database for both Argentina (1993-2001 and 2002-2005) and Uruguay (1993-2002 and 2003). From the same source we also calculate the ratio of government debt service (including short-term debt) to GDP. The rationale for this second measure is that, in our one-period bond model the entire stock of debt needs to be rolled over, so that an annual proxy for total debt service may be a more appropriate benchmark than the total debt stock to GDP. ${ }^{21}$

Table 2: Argentina: Simulated Moments

Non-business Cycle Statistics

\begin{tabular}{|c|c|c|c|c|}
\hline & Data & Model & Arellano (2008) & Yue (2010) \\
\hline \multicolumn{5}{|l|}{ Target Statistics } \\
\hline Default Probability (\%) & 3.26 & 3.50 & 3.00 & 2.67 \\
\hline Average Recovery Rate (\%) & 25.0 & 25.6 & - & 27.3 \\
\hline Restructuring choice & Post-default & ost-default & - & Post-default \\
\hline \multicolumn{5}{|l|}{ Non-Target Statistics } \\
\hline \multicolumn{5}{|l|}{ Before default / renegotiation } \\
\hline Average Debt/GDP ratio (\%) $1 /$ & $45.4 / 8.0$ & 7.7 & 5.95 & 10.1 \\
\hline Corr. (Spreads, Output) & -0.88 & -0.18 & -0.29 & -0.11 \\
\hline Bond Spreads: Average (\%) & 9.4 & 2.9 & 3.58 & 1.86 \\
\hline Bond Spreads: Std. Dev. (\%) & 7.6 & 4.2 & 6.38 & 1.58 \\
\hline Corr. (Debt/GDP, Spreads) 1/ & $0.92 / 0.93$ & 0.29 & - & - \\
\hline Corr. (Debt/GDP, Output) 1/ & $-0.97 /-0.99$ & -0.19 & - & - \\
\hline \multicolumn{5}{|l|}{ During debt renegotiation } \\
\hline Average Debt/GDP ratio (\%) 1/ & $130.5 / 29.1$ & 8.0 & - & - \\
\hline Corr. (Debt/GDP, Recovery Rates) & 0.25 & 0.256 & - & 0.273 \\
\hline Corr. (Debt/GDP, Output) 1/ & $-0.95 /-0.68$ & -0.18 & - & - \\
\hline Duration of Renegotiation/Exclusion (quarters & 14.0 & 5.8 & - & 1.0 \\
\hline Average Output Deviation (\%) & -4.5 & -3.4 & - & - \\
\hline
\end{tabular}

Sources: Arellano (2008), Datastream, IMF WEO, MECON, Yue (2010)

1/ Our main measure of indebtedness is total external debt to GDP (stock, in \%). In addition, we also show a second measure in some cases, namely annual debt service to GDP (flow, in \%). This figure may be the more appropriate benchmark, since in our one-period model the entire stock of debt needs to be rolled over.

\subsubsection{Simulation Results for Argentina (Post-default)}

Table 2 shows the simulation results for Argentina. ${ }^{22}$ We compare the moments simulated from the model (column 2) to those in the data (column 1), as well as to previous results from models focusing on the Argentine default, in particular Arellano (2008) and Yue (2010). Similar to conventional models replicating Argentina default, our model replicates

\footnotetext{
${ }^{21}$ In our model, interest payments are included in the total principal debt servicing after the income realization (the one-period zero-coupon bonds are sold at a price below par, but repaid at par). We therefore compare the simulated debt servicing cost from our model to data on total debt service (principal plus interest) and find the moments to match reasonably well (see Tables 2 and 3).

${ }^{22}$ The simulated business cycle statistics for both Argentina and Uruguay are reported in Appendix J.
} 
the relationship between bond spreads, debt/GDP and output in pre-default periods and average debt/GDP reasonably well. ${ }^{23}$

The calibration results outperform previous studies in which only post-default restructuring takes place, in particular Yue (2010). First, we produce higher average bond spreads and a higher standard deviation of spreads in the pre-default period, thus moving closer to the data. The reason behind is that spreads in our model take into account not only the sovereign's expected default choice, but also the expected choice for a preemptive restructuring. Second, our model produces a longer duration of exclusion/debt renegotiation and accounts for a large average output deviation during renegotiation. The simulated duration is significantly longer than in Yue (2010), although it is still shorter than in the data.

\subsubsection{Simulation Results for Uruguay (preemptive)}

Our second case is the preemptive restructuring for Uruguay. Unlike Argentina, we cannot benchmark our results to previous work, simply because there are no previous papers studying the case of Uruguay, or more generally, preemptive sovereign debt restructurings with haircuts. Instead, we contrast our results with a conventional model with only postdefault restructuring as Yue (2010), Bi (2008), and Asonuma (2012). The simulations perform well with regard to the relations among spreads, output, and debt/GDP ratio and average debt/GDP ratio in the pre-restructuring periods as in a model with only post-default restructurings.

The results show that introducing an option for preemptive restructurings improves the fit with the data, in at least three important ways. First, our simulated default probability is close to the data and lower than a model with only post-default restructuring. Our model correctly predicts Uruguay's decision for a preemptive restructuring and, thus, for not defaulting. Second, our model generates a higher average debt/GDP ratio during restructurings, similar to the data. The level of debt at the start of renegotiation is high, consistent with our prediction that a preemptive restructuring only happens with a high risk of default. Lastly, our model produces a duration of 1 quarter only, which matches the data for Uruguay perfectly. This is because the output costs are less severe compared to post-default cases so that the recovery to the pre-restructuring output level is quickly achieved, facilitating the debt exchange. In a model with only post-default restructuring, the simulated delay for Uruguay is 2.4 quarters. Appendix K provides further robustness checks for the preemptive case of Uruguay.

\section{Testing the Model Predictions}

An important result of our model is that a country will only initiate a preemptive debt restructuring when its default risk is high. To test this prediction, we assess the determinants

\footnotetext{
${ }^{23}$ The simulated moment does not match the data on debt/GDP stocks, but this may be the result of our timing structure, since we have a one-period bond model and no maturities above one year. As a result, the entire stock of debt needs to be rolled over each period (debt service burden $=$ debt stock).
} 
Table 3: Uruguay: Simulated Moments

Non-business Cycle Statistics

\begin{tabular}{|c|c|c|c|}
\hline & 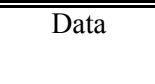 & Model & $\begin{array}{c}\text { Model without } \\
\text { preemptive restructuring }\end{array}$ \\
\hline \multicolumn{4}{|l|}{ Target Statistics } \\
\hline Default Probability (\%) & 3.26 & 3.95 & 4.67 \\
\hline Average Recovery Rate (\%) & 87.1 & 83.0 & 22.1 \\
\hline Restructuring choice & Preemptive & Preemptive & Post-default \\
\hline \multicolumn{4}{|l|}{ Non-Target Statistics } \\
\hline \multicolumn{4}{|l|}{ Before default / renegotiation } \\
\hline Average Debt/GDP ratio (\%) $1 /$ & $59.1 / 13.1$ & 14.2 & 12.5 \\
\hline Corr. (Spreads, Output) & -0.73 & -0.27 & -0.54 \\
\hline Bond Spread: Average (\%) & 7.7 & 1.7 & 2.2 \\
\hline Bond Spreads: Std. Dev. (\%) & 5.1 & 2.6 & 3.0 \\
\hline Corr. (Debt/GDP, Spreads) 1/ & $1.00 / 1.00$ & 0.08 & 0.24 \\
\hline Corr. (Debt/GDP, Output) 1/ & -0.77 & -0.21 & -0.30 \\
\hline \multicolumn{4}{|l|}{ During debt renegotiation } \\
\hline Average Debt/GDP ratio (\%) $1 /$ & $130.5 / 29.1$ & 40.0 & 17.6 \\
\hline Corr. (Debt/GDP, Recovery Rates) & 87.1 & 83.0 & 22.1 \\
\hline Corr. (Debt/GDP, Output) 1/ & n.a. & 0.021 & -0.16 \\
\hline Duration of Renegotiation/Exclusion (quarters) & 1.0 & 1.0 & 2.4 \\
\hline Average Output Deviation (\%) $2 /$ & $-6.4 /-2.3$ & -1.6 & -2.1 \\
\hline
\end{tabular}

Sources: Datastream, IMF WEO, Banco Central de Uruguay.

1/ Our main measure of indebtedness is total external debt to GDP (stock, in \%). In addition, we also show a second measure in some cases, namely annual debt service to GDP (flow, in \%). This figure may be the more appropriate benchmark, since in our one-period model the entire stock of debt needs to be rolled over.

2/ We report two measures of output deviations; output deviation over the debt restructuring period (2003Q2), which was -6.4 percent and the deviation during the 3 quarters around the restructuring period 2003Q2 - 2003Q4, which was -2.3 percent. Because the output deviation in 2003Q2 was largely distorted by the banking crisis that happen just prior the to the debt restructuring, we prefer using the average output deviation over 3 quarters.

of preemptive versus post-default debt exchanges using a multinomial logit model with yearly data and for a large panel of 138 developing countries with a population exceeding 500,000 (the underlying panel dataset is again borrowed from Trebesch and Zabel (2014)). The dependent variable captures the onset of a preemptive or post-default restructuring spell, building on the dataset described in Section 2. Specifically, the ordered dependent variable takes a value of 1 for the start year of preemptive renegotiations and a value of 2 for the start of a default that results in a post-default restructuring. The variable is 0 for all other years.

As explanatory variables we use proxies for indebtedness and default risk that are available for a large sample of countries. In the model, the default probability ex-ante will depend on the level of accumulated debt and, thus, on the debt service burden and expected income in the next period. We therefore use public debt to GDP as a proxy, using historical data from the IMF. We also use data on private sector debt to GDP, which is another proxy for the country's level of accumulated debt. Furthermore, we use real per capita GDP growth and changes in the terms of trade to proxy a country's ability to pay. These variables all come from the World Bank's WDI dataset. Lastly, we rely on country credit ratings data from the Institutional Investor magazine, which have a good 
historical coverage and are widely used in related work (e.g. Reinhart and Rogoff (2009)). The ratings are forward looking and measured on a scale from 0 (minimum rating) to 100 (maximum rating). ${ }^{24}$ In line with the crisis prediction literature, we compute 3-year moving averages of each explanatory variable and lag them by one year.

Table 4: Predicting Preemptive and Post-Default Restructurings

\begin{tabular}{|c|c|c|c|c|c|c|c|c|c|c|c|c|}
\hline & \multicolumn{2}{|c|}{$\begin{array}{c}(1) \\
\text { Debt/GDP }\end{array}$} & \multicolumn{2}{|c|}{$\begin{array}{c}(2) \\
\text { Change in } \\
\text { Debt/GDP }\end{array}$} & \multicolumn{2}{|c|}{$\begin{array}{c}(3) \\
\text { Change in } \\
\text { Ratings }\end{array}$} & \multicolumn{2}{|c|}{$\begin{array}{c}(4) \\
\text { Change in } \\
\text { Terms of Trade }\end{array}$} & \multicolumn{2}{|c|}{$\begin{array}{c}(5) \\
\text { Real Growth }\end{array}$} & \multicolumn{2}{|c|}{$\begin{array}{c}(6) \\
\text { Full Model }\end{array}$} \\
\hline & $\begin{array}{c}\text { preempt. } \\
\text { coef } / \mathrm{se}\end{array}$ & $\begin{array}{c}\text { post-def. } \\
\text { coef/se }\end{array}$ & $\begin{array}{c}\text { preempt. } \\
\text { coef } / \mathrm{se}\end{array}$ & $\begin{array}{c}\text { post-def. } \\
\text { coef/se }\end{array}$ & $\begin{array}{c}\text { preempt. } \\
\text { coef/se }\end{array}$ & $\begin{array}{c}\text { post-def. } \\
\text { coef/se }\end{array}$ & $\begin{array}{c}\text { preempt. } \\
\text { coef/se }\end{array}$ & $\begin{array}{c}\text { post-def. } \\
\text { coef/se }\end{array}$ & $\begin{array}{c}\text { preempt. } \\
\text { coef/se }\end{array}$ & $\begin{array}{c}\text { post-def. } \\
\text { coef/se }\end{array}$ & $\begin{array}{c}\text { preempt. } \\
\text { coef/se }\end{array}$ & $\begin{array}{c}\text { post-def. } \\
\text { coef/se }\end{array}$ \\
\hline Level of Public Debt/GDP & $\begin{array}{l}-0.00 \\
(0.00)\end{array}$ & $\begin{array}{c}0.00 \\
(0.00)\end{array}$ & & & & & & & & & & \\
\hline Level of Private Debt/GDP & $\begin{array}{l}0.01^{* *} \\
(0.00)\end{array}$ & $\begin{array}{l}-0.00 \\
(0.00)\end{array}$ & & & & & & & & & $\begin{array}{l}0.01^{* *} \\
(0.00)\end{array}$ & $\begin{array}{l}-0.01 \\
(0.01)\end{array}$ \\
\hline $\begin{array}{l}\text { Change in Debt/GDP } \\
\text { (3-year moving average) }\end{array}$ & & & $\begin{array}{c}0.005 * * \\
(0.00)\end{array}$ & $\begin{array}{c}0.00 \\
(0.00)\end{array}$ & & & & & & & & \\
\hline $\begin{array}{l}\text { Change in Instit. Investor } \\
\text { Ratings (3-year mov avg) }\end{array}$ & & & & & $\begin{array}{c}-0.36^{* * *} \\
(0.05)\end{array}$ & $\begin{array}{c}-0.23 * * * \\
(0.05)\end{array}$ & & & & & $\begin{array}{c}-0.29 * * * \\
(0.07)\end{array}$ & $\begin{array}{c}-0.18 * * * \\
(0.06)\end{array}$ \\
\hline $\begin{array}{l}\text { Change in Terms of Trade } \\
\text { (3-year moving average) }\end{array}$ & & & & & & & $\begin{array}{c}-0.10^{* * *} \\
(0.02)\end{array}$ & $\begin{array}{l}-0.01 \\
(0.03)\end{array}$ & & & & \\
\hline $\begin{array}{l}\text { Real Growth Rate } \\
\text { (3-year moving average) }\end{array}$ & & & & & & & & & $\begin{array}{c}-0.09^{* * *} \\
(0.02)\end{array}$ & $\begin{array}{c}-0.05^{* *} \\
(0.02)\end{array}$ & $\begin{array}{c}-0.14 * * * \\
(0.04)\end{array}$ & $\begin{array}{l}-0.05 \\
(0.04)\end{array}$ \\
\hline Constant & $\begin{array}{c}-4.89 * * * \\
(0.30)\end{array}$ & $\begin{array}{c}-4.09 * * * \\
(0.25)\end{array}$ & $\begin{array}{c}-4.87 * * * \\
(0.29)\end{array}$ & $\begin{array}{c}-4.50^{* * *} \\
(0.22)\end{array}$ & $\begin{array}{c}-5.06^{* * *} \\
(0.33)\end{array}$ & $\begin{array}{c}-4.66 * * * \\
(0.24)\end{array}$ & $\begin{array}{c}-4.94 * * * \\
(0.33)\end{array}$ & $\begin{array}{c}-4.38^{* * *} \\
(0.22)\end{array}$ & $\begin{array}{c}-4.97 * * * \\
(0.26)\end{array}$ & $\begin{array}{c}-4.50 * * * \\
(0.19)\end{array}$ & $\begin{array}{c}-5.60 * * * \\
(0.41)\end{array}$ & $\begin{array}{c}-4.32 * * * \\
(0.30)\end{array}$ \\
\hline Observations & 29 & 73 & & 375 & 22 & 40 & 203 & & 31 & 49 & & 127 \\
\hline Pseudo R2 & 0.0 & 006 & & 001 & 0.0 & 082 & 0.0 & & & 015 & & 099 \\
\hline
\end{tabular}

The table shows coefficients from a multinomial logit model. The dependent variable is the onset of preemptive and post-default restructurings.

Significance denoted by ${ }^{* * *} \mathrm{p}<0.01,{ }^{* *} \mathrm{p}<0.05,{ }^{*} \mathrm{p}<0.10$. All expl. variables are lagged by one year. Robust s.e. clustered on country in parentheses.

Table 4 shows the results. In line with our model, we find that a higher default risk, as proxied by high private sector debt and a decline in growth and terms of trade, increase the probability of preemptive debt restructurings. In contrast, the level of debt to GDP is insignificant (as in Erce 2013). Changes in country credit ratings are a significant predictor for both types of crises. These variables are also economically significant. In Column (6), a one standard deviation decline in ratings or of real growth is associated with a 0.5 percentage point higher likelihood of initiating a preemptive restructuring. This (small) marginal effect corresponds to a $50 \%$ increase in the probability of initiating a preemptive renegotiaton (the share of years with an onset of preemptive restructurings is just $0.9 \%$ in the data).

Overall, we conclude that preemptive debt renegotiations are relatively easy to predict with lagged data. They are significantly more likely when macroeconomic fundamentals have deteriorated over the past years and when default risk is high, as predicted by our model. This can also be seen in the raw data: on average, the Institutional Investor ratings decline by $30 \%$ in the three years prior to the start of preemptive debt renegotiations (this is three times the standard deviation in rating changes). In contrast, the occurrence of post-default restructurings is harder to predict using historical data. Most lagged macro

\footnotetext{
${ }^{24}$ Alternative risk proxies such as bond spreads, Creditr Default Swap (CDS) premia or agency ratings by $\mathrm{S} \& \mathrm{P}$ or Moody's have a reasonable coverage only from the late 1990s onwards and thus include less then $30 \%$ of our sample.
} 
variables are insignificant and ratings drop much less pre-crisis (by less than 10\%, on average), and much more once the crisis starts. Post-default crises thus seem to occur after unexpected bad shocks, which is again in line with our model setup and results.

\section{Conclusion}

This paper studies two alternative strategies to resolve a sovereign debt crisis: preemptive and post-default restructurings. We code a new monthly crisis dataset and find that preemptive restructurings occur with surprising frequency. We then attempt to rationalize why sovereigns initiate preemptive vs. post-default restructurings and incorporate these two types of renegotiation into a dynamic model of defaultable debt. The simulation results match the data well and our model with a preemptive option performs significantly better than the conventional setup with only post-default restructuring. This adds a new perspective to the growing literature on bargaining between creditors and debtors.

The paper also has implications for policy. We document that countries tend to initiate a preemptive restructuring when their default risk is high and that this strategy often succeeds in preventing a payment default in subsequent years. Furthermore, we show that preemptive deals are quicker to resolve, result in lower haircuts (less debt relief), and are associated with lower declines in output compared to post-default crises. These findings and our modeling strategy may help to inform the debate on sovereign debt and default, which has recently focused on the choice between preemptive and post-default debt restructurings. 


\section{References}

[1] Aguiar, Mark and Gita Gopinath (2006). "Defaultable Debt, Interest Rates and the Current Account." Journal of International Economics, 69(1), 64-83.

[2] Aguiar, Mark and Manuel Amador (2014). "Sovereign Debt." In:Handbook of International Economics, 4, 647-87.

[3] Arellano, Cristina (2008). "Default Risk and Income Fluctuations in Emerging Economies." American Economic Review, 98(3), 690-712.

[4] Arellano, Cristina and Yan Bai (2014). "Linkages across Sovereign Debt Markets," Working Paper, Federal Reserve Bank of Minneapolis.

[5] Arellano, Cristina, Xavier Mateos-Planas and Jose V. Rios-Rull (2013). "Partial Default." Working paper, Federal Reserve Bank of Minneapolis.

[6] Arellano, Cristina and Ananth Ramanarayanan (2012). "Default and the Maturity Structure in Sovereign Bonds." Journal of Political Economy, 120(2), 187-232.

[7] Asonuma, Tamon (2012). "Serial Default and Debt Renegotiation." Working paper, International Monetary Fund.

[8] Asonuma, Tamon and Hyungseok Joo (2014). "Sovereign Debt Restructurings: Delay in Renegotiation and Risk-Averse Creditors." Working Paper, International Monetary Fund.

[9] Asonuma, Tamon, Gerardo Peraza, Kristine Vitola, and Takahiro Tsuda (2014). "Sovereign Debt Restructurings in Belize: Achievements and Challenges Ahead." IMF Working Paper 14/132.

[10] Bai, Yan and Jing Zhang (2010). "Duration of Sovereign Debt Renegotiation." Journal of International Economics, 86(2), 252-268.

[11] Benjamin, David and Mark L.J. Wright (2009). "Recovery Before Redemption? A Theory of Delays in Sovereign Debt Renegotiations." Working Paper, University of California, Los Angeles.

[12] Bi, Ran (2008). "'Beneficial" Delays in Debt Restructuring Negotiations." IMF Working Paper 08/38.

[13] Bolton, Patrick and Olivier Jeanne (2007). "Structuring and Restructuring Sovereign Debt: The Role of a Bankruptcy Regime." Journal of Political Economy, 115(6), 901-924.

[14] Bolton, Patrick and Olivier Jeanne (2009). "Structuring and Restructuring Sovereign Debt: The Role of Seniority." Review of Economic Studies, 76(3), 879-902. 
[15] Borensztein Eduardo and Ugo Panizza (2009). "The Costs of Sovereign Default." IMF Staff Papers, 56(4), 683-741.

[16] Brookings-Committee on International Economic Policy and Reform (CEIPR) (2013). "Revisiting Sovereign Bankruptcy." Brookings Institution, October.

[17] Bulow, Jeremy and Kenneth S. Rogoff (1989). "Sovereign Debt: Is to Forgive or to Forget?" American Economic Review, 79, 43-50.

[18] Calvo, Guillermo A. (1988). "Servicing the Public Debt: The Role of Expectations." American Economic Review, 78(4), 647-661.

[19] Chatterjee, Satyajit and Burcu Eyigungor (2012). "Maturity, Indebtedness, and Default Risk." American Economic Review, 102(6), 2674-2699.

[20] Corsetti, Giancarlo and Luca Dedola (2013). "The Mystery of the Printing Press: Selffulfilling Debt Crises and Monetary Sovereignty." CEPR Discussion Paper No.9358.

[21] Cruces, Juan and Christoph Trebesch (2013). "Sovereign Defaults: The Price of Haircuts." American Economic Journal: Macroeconomics, 5(3), 85-117.

[22] Das, Udaibir S., Michael G. Papaioannou and Christoph Trebesch (2012) "Sovereign Debt Restructurings 1950-2010: Literature Survey, Data, and Stylized Facts." IMF Working Paper 12/203.

[23] De Paoli, Bianca, Glenn Hoggarth and Victoria Saporta (2009). "Output Costs of Sovereign Crises: Some Empirical Estimates." Bank of England Working Paper No.362.

[24] D'Erasmo, Pablo (2010). "Government Reputation and Debt Repeymant in Emerging Economies." Working Paper, University of Maryland.

[25] Diaz-Cassou, Javier, Aitor Erce and Juan Vazquez-Zamora (2008). "Recent Episodes of Sovereign Debt Restructurings. A Case-study Approach.” Banco de Espana Occasional Paper No.0804.

[26] Duggar, Elena (2013). "The Role of Holdout Creditors and CACs in Sovereign Debt Restructurings." Moody's Sovereign Default Series Compendium, October 7, 2013.

[27] Eaton, Jonathan, and Mark Gersovitz (1981). "Debt with Potential Repudiation: Theoretical and Empirical Analysis." Review of Economic Studies, 48, 289-309.

[28] Enderlein, Henrik, Christoph Trebesch and Laura von Daniels (2012). "Sovereign Debt Disputes: A Database on Government Coerciveness During Debt Crises." Journal of International Money and Finance, 31(2), 250-266.

[29] Erce, Aitor (2013). "Sovereign Debt Restructurings and the IMF: Implications for Future Official Interventions." Federal Reserve Bank of Dallas Working Paper 143. 
[30] Fernandez, Raquel and Alberto Martin (2014). "The Long and the Short of It: Sovereign Debt Crises and Debt Maturity." NBER Working Paper No.20786.

[31] Finger, Harald and Mauro Mecagni (2007). "Sovereign Debt Restructuring and Debt Sustainability - An Analysis of Recent Cross-Country Experience." IMF Occasional Paper No. 255.

[32] Friedman, Irving S. (1983). The World Debt Dilemma: Managing Country Risk, Washington, D.C.: Council for International Banking Studies.

[33] Gelos, Gaston, Ratna Sahay and Guido Sandleris (2011). "Sovereign Borrowing by Developing Countries: What Determines Market Access?" Journal of International Economics, 83(2), 243-254.

[34] Hatchondo, Juan C. and Leonardo Martinez (2009). "Long-Duration Bonds and Sovereign Defaults." Journal of International Economics, 79(1), 117-125.

[35] Hatchondo, Juan C., Leonardo Martinez and Cesar Sosa Padilla (2014). "Voluntary Sovereign Debt Exchanges." Journal of Monetary Economics, 61, 32-50.

[36] International Monetary Fund (2013). "Sovereign Debt Restructuring: Recent Developments and Implications for the Fund's Legal and Policy Framework." IMF Board Paper, March.

[37] Kovrijnykh, Natalia and Balazs Szentes (2007). "Equilibrium Default Cycles." Journal of Political Economy, Vol. 115(3), 403-446.

[38] Laeven, Luc and Fabian Valencia (2012). "Systemic Banking Crises Database: An Update." IMF Working Paper 12/163.

[39] Levy-Yeyati, Eduardo and Ugo Panizza (2011). "The Elusive Costs of Sovereign Defaults." Journal of Development Economics, 94(1), 95-105.

[40] Manasse, Paolo and Nouriel Roubini (2009). "'Rules of Thumb' for Sovereign Debt Crises." Journal of International Economics, 78(2), 192-205.

[41] Mendoza, Enrique G. and Vivian Z. Yue (2012). "A General Equilibrium Model of Sovereign Default and Business Cycles." The Quarterly Journal of Economics, 127(2), 889-946.

[42] Panizza, Ugo, Federico Sturzenegger and Jeromin Zettelmeyer (2009). "The Economics and Law of Sovereign Debt and Default." Journal of Economic Literature, 47(3), 651698.

[43] Pitchford, Rohan and Mark L.J. Wright (2012). "Holdouts in Sovereign Debt Restructurings: A Theory of Negotiations in a Weak Contractual Environment." Review of Economic Studies, 79(2), 812-837. 
[44] Reinhart, Carmen M. and Kenneth S. Rogoff (2009). This Time is Different. Eight Centuries of Financial Folly. Princeton University Press, Princeton.

[45] Rieffel, Lex (2003). Restructuring Sovereign Debt: The Case for Ad Hoc Machinery. Washington, D.C.: Brookings Institution Press.

[46] Roubini, Nouriel and Brad Setser (2004). Bailouts or Bail-ins? Responding to Financial Crises in Emerging Economies. Institute for International Economics, Washington, D.C.

[47] Sachs, Jeffrey and Harry Huizinga (1987). "U.S. Commercial Banks and the DevelopingCountry Debt Crisis." Brookings Papers on Economic Activity, 18(2), 555-606.

[48] Schumacher, Julian, Christoph Trebesch and Henrik Enderlein (2014). "Sovereign Defaults in Court." Working Paper, University of Munich.

[49] Stamm, Hanspeter (1987). Kooperation und Konflikt im Weltfinanzsystem. Eine Analyse multilateraler Umschuldungsaktionen seit 1956., Soziologisches Institut der Universitat Zurich.

[50] Standard and Poor's (2006). "Default Study: Sovereign Defaults At 26-Year Low, To Show Little Change In 2007." September 18, 2006.

[51] Sturzenegger, Federico (2004). "Tools for the Analysis of Debt Problems." Journal of Restructuring Finance, 1, 201-223.

[52] Sturzenegger, Federico and Jeromin Zettelmeyer (2006). Debt Defaults and Lessons from a Decade of Crises. MIT Press.

[53] Sturzenegger, Federico and Jeromin Zettelmeyer (2008). "Haircuts: Estimating Investor Losses in Sovereign Debt Restructurings, 1998-2005." Journal of International Money and Finance, 27(5), 780-805.

[54] Tauchen, George (1986). "Finite State Markov-chain Approximations to Univariate and Vector Autoregressions." Economic Letters, 20(2), 177-181.

[55] Tomz, Michael and Mark L.J. Wright (2007) "Do Countries Default in "Bad" Times?" Journal of European Economic Association, 5(2-3), 352-360.

[56] Trebesch, Christoph (2011). "Debt Restructuring Delays: Measurement and Stylized Facts." In: Kolb, R. (Ed.): Sovereign Debt: From Safety to Default. Hoboken: Wiley, 169-177.

[57] Trebesch, Christoph (2013). "Delays in Sovereign Debt Restructurings." Working Paper, University of Munich.

[58] Trebesch, Christoph and Michael Zabel (2014). "The Output Costs of Hard and Soft Sovereign Default." Working Paper, University of Munich. 
[59] Yue, Vivian Z. (2010). "Sovereign Default and Debt Renegotiation." Journal of International Economics, 80(2), 176-187. 


\section{Appendix A Dataset: Coding Examples}

Coding details and references for the first 7 restructurings (by alphabet):

Albania 08/1995 Post-default: Substantial arrears to private creditors since at least Dec. 1991, when the restructuring was announced ( $>5 \%$ of debt stock in arrears according to GDF). See also (Reuters, 14 Nov. 1991) (Reuters, 17 Nov. 1991) (Reuters, 10 July 1992) (Reuters, 24 April 1993) (Reuters, 8 July 1994) (Reuters, 11 May 1995) (Reuters, 12 May 1995) (FT, 12 May 1995) (Reuters, 31 August 1995) (Reuters, 27 July 1995) (Reuters, 28 July 1995).

Algeria 03/1992 Strictly preemptive: No missed payments until 1994 (FT, 28 Jan. 1991) (WSJ, 18 October 1990) (Reuters, 25 July 1990) (Reuters, 20 Sept. 1991) (WSJ, 23 Sept. 1991) (Reuters, 9 Oct. 1991) (Reuters, 4 March 1992). No arrears according to GDF.

Algeria 07/1996 Post-default: Partial and temporary payment suspensions in the period from March 1994 to 1995. Interest payments continue throughout. Principal payments are cleared in 1995 (Reuters, 24 Aug. 1993) (Reuters, 13 Dec. 1993) (Reuters, 18 Dec. 1993) (Reuters, 13 Jan. 1994) (Reuters, 17 April 1994) (Reuters, 27 Sept. 1994) (Reuters, 12 May 1995) (FT, 13 May 1995) (Reuters, 28 Sept. 1995) (Reuters, 17 July 1996) (Reuters, 19 July 1996) (WSJ, 22 July 1996).

Argentina 08/1985 Post-default: Considerable, non-negotiated arrears in 1983, 1984 and 1985 (FT, 3 July 1982) (WSJ, 21 June 1982) (FT, 3 Sept. 1982) (WSJ, 18 Oct. 1982) (FT, 13 Dec. 1982) (FT, 26 Jan. 1983) (FT, 28 Jan. 1983) (Boughton, 2001, p. 385) (WSJ, 21 June 1982) (FT, 29 July 1982) (WSJ, 27 Sept. 1982) (FT, 21 Sept. 1982) (FT, 12 Jan. 1984) (NYT, 16 Dec. 1983) (FT, 15 Dec. 1983) (WSJ, 17 Jan. 1984) (FT, 8 March 1984) (FT, 19 June 1984) (NYT, 12 June 1985) (WSJ, 24 June 1985) (FT, 8 March 1984) (NYT, 23 Sept. 1984) (WSJ, 24 June 1985).

Argentina 08/1987 Weakly preemptive: Some missed payments, but these are agreed with the Bank Advisory Committee. The majority of debt coming due continues to be serviced. Rollover agreements on medium and long term principal are agreed in April and Sept. 1986. (NYT, 27 Aug. 1985) (AP, 25 April 1986) (FT, 9 Sept.1986) (NYT, 24 Februar 1987) (WSJ, 15 April 1987) (FT, 15 April 1987) (AP, 10 Sept. 1987) (Dow Jones News Service, 21 August 1987) (Aggarwal, 1996, p. 433) (FT, 21 August 1987).

Argentina 04/1993 Post-default: Considerable arrears after March 1988. Arrears increase strongly until the restructuring agreement in 1993 (GDF data) (Aggarwal, 1996, p. 449) (Reuters, 3 Febr. 1988) (FT, 18 June 1988) (WSJ, 1 July 1988) (FT, 21 Oct. 1988) (FT, 7 March 1989) (Reuters, 3 Febr. 1988) (WSJ, 4 Aug. 1988) (FT, 15 Sept. 1988) (WSJ, 21 Dec. 1988) (Reuters, 30 Jan. 1989) (Reuters, 3 Febr. 1988) (FT, 7 March 1989) (Reuters, 24 April 1989) (FT, 6 Aug. 1988) (Reuters, 17 June 1989) (AP, 7 June 1990) (Reuters, 7 June 1990) (Reuters, 3 Aug. 1990) (Reuters, 8 Jan. 1991) (Reuters, 15 Sept. 1991) (Reuters, 3 Febr. 1988) (Reuters, 3 Febr. 1988) (FT, 18 June 1988) (FT, 7 March 1989) (Reuters, 6 Oct. 1989) (Reuters, 15 May 1989) (Reuters, 7 June 1989) (WSJ, 2 Oct. 1989) (FT, 2 Sept. 1988 and FT, 12 Sept. 1988) (WSJ, 4 Aug. 1988) (FT, 15 Sept. 1988) (Reuters, 30 Jan. 1992) (FT, 1 Febr. 1992) (Reuters, 6 Oct. 1989) (Reuters, 7 May 1990) (Reuters, 1 Oct. 1990) (Reuters, 25 Sept. 1990) (Reuters, 8 May 1991) (Reuters, 9 Sept. 1991) (Reuters, 18 Nov. 1991) (NYT, 8 April 1992) (FT, 8 April 1992) (FT, 25 June 1992) (Reuters, 7 April 1993) (Reuters, 6 Dec. 1992). 


\section{Appendix B Dataset: Selected Recent Restructurings}

Table B.1: Classification of Selected Recent Sovereign Restructurings (1998-2010)

\begin{tabular}{lccl}
\hline \hline Case & $\begin{array}{c}\text { Start (Default or } \\
\text { Anouncement) }\end{array}$ & $\begin{array}{c}\text { Final } \\
\text { exchange }\end{array}$ & Type of Exchange \\
\hline Pakistan (External bonds) & Jan-99 & Dec-99 & Preemptive (strictly) \\
Ukraine OVDPs (non-residents) & Aug-98 & Sep-98 & Preemptive (strictly) \\
Ukraine (Global Exchange) & Jan-00 & Apr-00 & Preemptive (weakly) \\
Russia (GKOs of non-residents) & Aug-98 & May-99 & Post-default \\
Russia (PRINs \& IANs) & Nov-98 & Aug-00 & Post-default \\
Ecuador (External bonds) & Jan-99 & Aug-00 & Post-default \\
Moldova 02 (Eurobond) & Jun-02 & Oct-02 & Preemptive (strictly) \\
Uruguay (External bonds) & Mar-03 & May-03 & Preemptive (strictly) \\
Dominica (External bonds and loans) & Jul-03 & Jun-04 & Preemptive (weakly) \\
Dominican Republic (External bonds) & Apr-04 & May-05 & Preemptive (strictly) \\
Argentina (Global exchange) & Nov-01 & Jun-05 & Post-default \\
Grenada (External bonds and loans) & Oct-04 & Nov-05 & Preemptive (weakly) \\
Belize (External bonds and loans) & Aug-06 & Feb-07 & Preemptive (weakly) \\
Ecuador (External bond buy-back) & Nov-08 & Jun-09 & Post-default \\
Seychelles (External bonds) & Jul-08 & Feb-10 & Post-default \\
Cote d'Ivoire (External bonds) & Mar-00 & Apr-10 & Post-default \\
\hline \hline
\end{tabular}




\section{Appendix C Additional Descriptive Figures}

Figure C.1: Preemptive and Post-default Restructurings by Country (1978-2010)
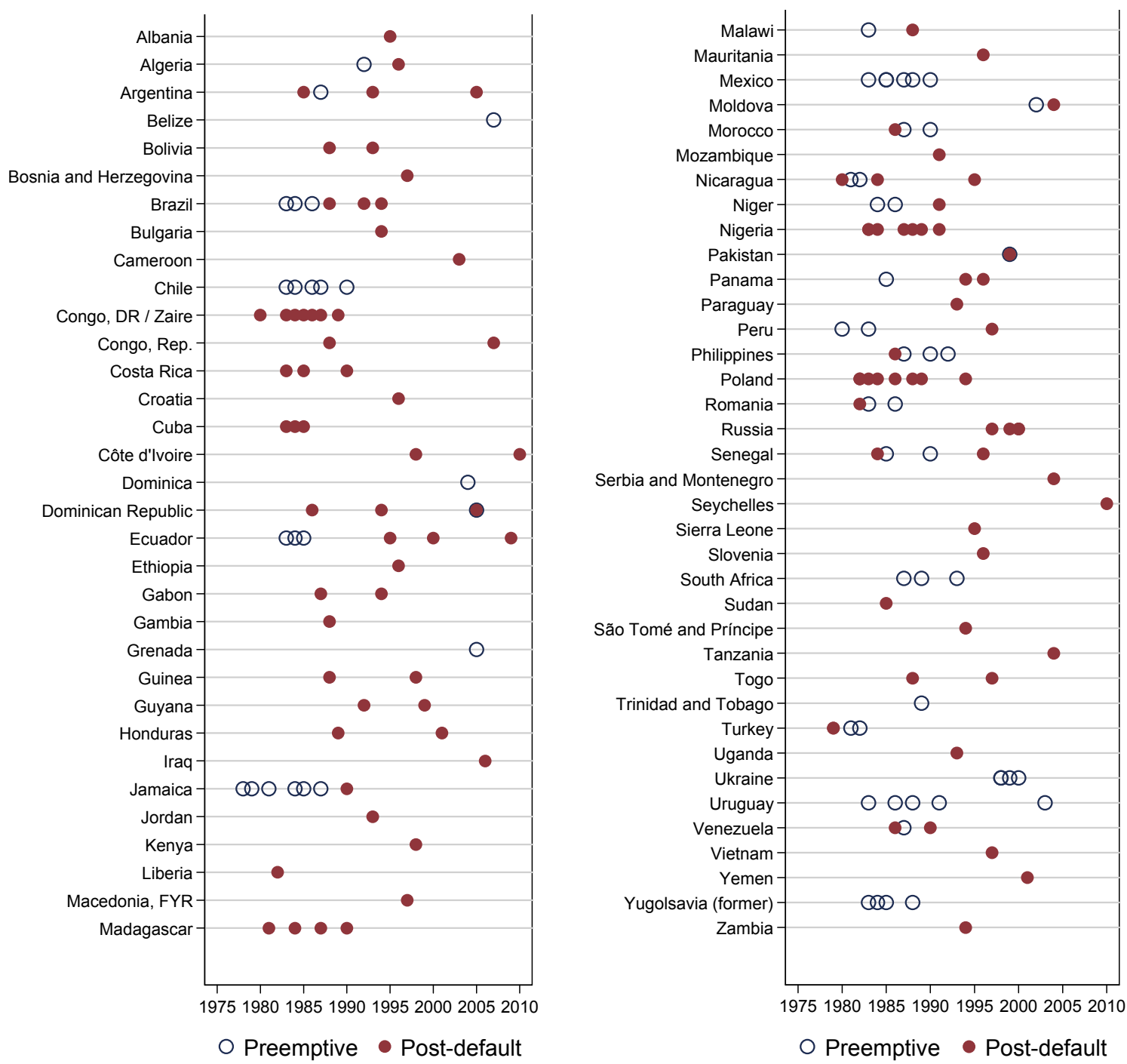
Figure C.2: Haircuts by Type of Restructuring (1978-2010)

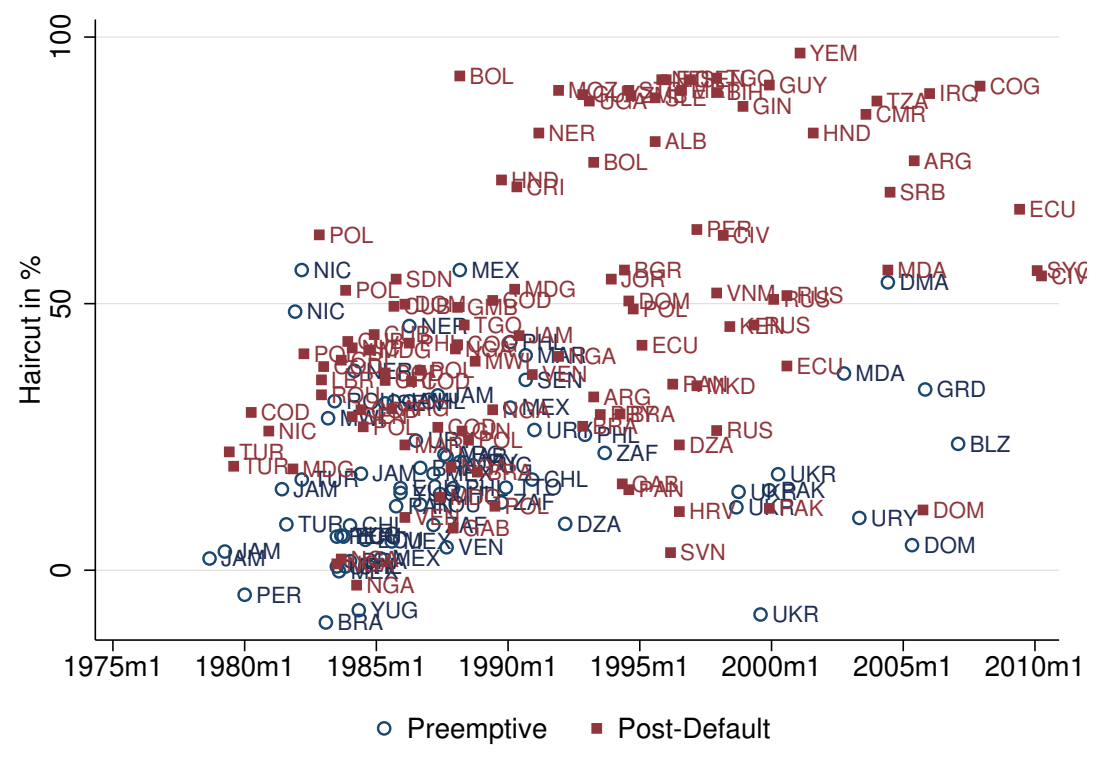

This figure shows a scatter plot of haircut size by type of restructuring (preemptive vs post-default) from the mid-1970s until 2010. Nearly all restructurings with haircuts above 50\% occurred since 1990 and most of them were post-default cases (red colored).

Figure C.3: Kaplan-Meier Survival Functions for Restructuring Duration

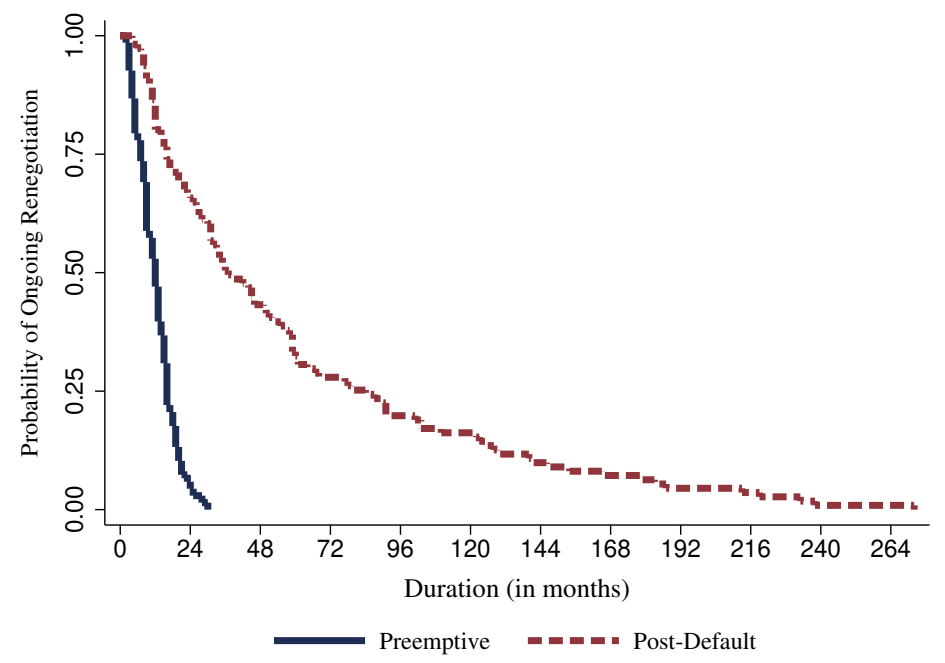

This figure plots a non-parametric Kaplan-Meier survival function for both types of restructurings. The vertical axis reports the unconditional compound probability of continuing negotiations (i.e. of not having completed a restructuring) - for each month after the start of the crisis (shown on the horizontal axis). 


\section{Appendix D Regression Results: Output Growth}

Table D.1: Real per capita GDP Growth During Debt Crises

\begin{tabular}{|c|c|c|c|c|c|c|}
\hline & All crises & $\begin{array}{l}\text { All crises, } \\
\text { with controls }\end{array}$ & $\begin{array}{l}\text { Preemptive } \\
\text { only }\end{array}$ & $\begin{array}{l}\text { Preemptive, } \\
\text { with controls }\end{array}$ & $\begin{array}{l}\text { Post-default } \\
\text { only }\end{array}$ & $\begin{array}{l}\text { Post-default, } \\
\text { with controls }\end{array}$ \\
\hline & (1) & (2) & (3) & (4) & (5) & (6) \\
\hline & coef/se & coef/se & coef/se & coef/se & coef/se & coef/se \\
\hline Debt Crisis (start year) & $\begin{array}{c}-3.46^{* * * *} \\
(0.98)\end{array}$ & $\begin{array}{l}-2.89 * * * \\
(0.65)\end{array}$ & $\begin{array}{l}-1.33 \\
(1.01)\end{array}$ & $\begin{array}{l}-1.44^{*} \\
(0.81)\end{array}$ & $\begin{array}{c}-2.67 * * \\
(1.29)\end{array}$ & $\begin{array}{c}-2.38^{* * *} \\
(0.91)\end{array}$ \\
\hline Debt Crisis (start, lag 1) & $\begin{array}{l}-2.74 * * * \\
(0.92)\end{array}$ & $\begin{array}{c}-2.18 * * \\
(0.86)\end{array}$ & $\begin{array}{c}0.34 \\
(0.87)\end{array}$ & $\begin{array}{l}-0.38 \\
(0.94)\end{array}$ & $\begin{array}{l}-3.23^{* * *} \\
(1.16)\end{array}$ & $\begin{array}{l}-2.52^{* *} \\
(1.06)\end{array}$ \\
\hline Debt Crisis (start, lag 2) & $\begin{array}{c}0.42 \\
(0.68)\end{array}$ & $\begin{array}{c}0.49 \\
(0.70)\end{array}$ & $\begin{array}{l}2.13^{* * *} \\
(0.72)\end{array}$ & $\begin{array}{l}1.91 * * \\
(0.80)\end{array}$ & $\begin{array}{l}-0.18 \\
(0.83)\end{array}$ & $\begin{array}{l}-0.36 \\
(0.85)\end{array}$ \\
\hline Debt Crisis (start, lag 3) & $\begin{array}{l}1.60^{* *} \\
(0.65)\end{array}$ & $\begin{array}{l}1.04 \\
(0.72)\end{array}$ & $\begin{array}{c}0.98 \\
(0.79)\end{array}$ & $\begin{array}{c}0.94 \\
(0.89)\end{array}$ & $\begin{array}{l}1.52^{*} \\
(0.79)\end{array}$ & $\begin{array}{c}0.43 \\
(0.89)\end{array}$ \\
\hline Investment/GDP (in \%) & & $\begin{array}{c}12.87 * * * \\
(2.58)\end{array}$ & & $\begin{array}{c}13.33^{* * *} \\
(2.58)\end{array}$ & & $\begin{array}{c}13.17 * * * \\
(2.59)\end{array}$ \\
\hline Population (growth, in \%) & & $\begin{array}{l}-0.05 \\
(0.18)\end{array}$ & & $\begin{array}{l}-0.04 \\
(0.18)\end{array}$ & & $\begin{array}{l}-0.04 \\
(0.18)\end{array}$ \\
\hline Population (log) & & $\begin{array}{l}-3.67 \\
(2.97)\end{array}$ & & $\begin{array}{l}-3.63 \\
(3.06)\end{array}$ & & $\begin{array}{l}-3.85 \\
(3.00)\end{array}$ \\
\hline $\begin{array}{l}\text { Secondary Education } \\
\text { (share of population, in \%) }\end{array}$ & & $\begin{array}{c}-0.02 \\
(0.04)\end{array}$ & & $\begin{array}{l}-0.02 \\
(0.04)\end{array}$ & & $\begin{array}{l}-0.02 \\
(0.04)\end{array}$ \\
\hline Government & & $0.04 * *$ & & $0.04 * *$ & & $0.04 * *$ \\
\hline Consumption (lag) & & $(0.02)$ & & $(0.02)$ & & $(0.02)$ \\
\hline $\begin{array}{l}\text { Civil Liberties } \\
\text { (Freedom House) }\end{array}$ & & $\begin{array}{c}0.11 \\
(0.16)\end{array}$ & & $\begin{array}{c}0.07 \\
(0.17)\end{array}$ & & $\begin{array}{c}0.10 \\
(0.17)\end{array}$ \\
\hline $\begin{array}{l}\text { Terms of Trade } \\
\text { (change, in \%) }\end{array}$ & & $\begin{array}{l}5.67 * * * \\
(1.37)\end{array}$ & & $\begin{array}{l}5.64 * * * \\
(1.39)\end{array}$ & & $\begin{array}{l}5.61 * * * \\
(1.36)\end{array}$ \\
\hline $\begin{array}{l}\text { Openness in \% } \\
\text { (Trade/GDP) }\end{array}$ & & $\begin{array}{l}-0.01 \\
(0.01)\end{array}$ & & $\begin{array}{l}-0.01 \\
(0.01)\end{array}$ & & $\begin{array}{l}-0.01 \\
(0.01)\end{array}$ \\
\hline $\begin{array}{l}\text { Banking Crisis } \\
\text { (onset) }\end{array}$ & & $\begin{array}{c}-1.72 * * * \\
(0.63)\end{array}$ & & $\begin{array}{l}-1.88^{* * *} \\
(0.64)\end{array}$ & & $\begin{array}{c}-1.92 * * * \\
(0.63)\end{array}$ \\
\hline $\begin{array}{l}\text { Currency Crisis } \\
\text { (onset) }\end{array}$ & & $\begin{array}{l}-5.01 * * * \\
(1.07)\end{array}$ & & $\begin{array}{l}-5.23^{* * *} \\
(1.11)\end{array}$ & & $\begin{array}{c}-5.04 * * * \\
(1.09)\end{array}$ \\
\hline Constant & $\begin{array}{l}1.23 * * \\
(0.48)\end{array}$ & $\begin{array}{l}10.56 \\
(8.90)\end{array}$ & $\begin{array}{l}0.82^{*} \\
(0.48)\end{array}$ & $\begin{array}{l}10.64 \\
(9.13)\end{array}$ & $\begin{array}{l}1.21 * * \\
(0.49)\end{array}$ & $\begin{array}{l}10.90 \\
(8.98)\end{array}$ \\
\hline Country Fixed Effects & Yes & Yes & Yes & Yes & Yes & Yes \\
\hline Year Fixed Effects & Yes & Yes & Yes & Yes & Yes & Yes \\
\hline Observations & 3,334 & 1,971 & 3,334 & 1,971 & 3,334 & 1,971 \\
\hline Adjusted $R$-Squared & 0.052 & 0.243 & 0.047 & 0.233 & 0.051 & 0.238 \\
\hline
\end{tabular}

The table shows results from fixed effects OLS regressions. The dependent variable is annual per capita real GDP growth (in $\%$ ). The main explantory variable is a (lagged) dummy capturing the start of a crisis spell (default or anouncement of a restructuring). In columns 3 and 4 the debt crisis measure (and its lags) only captures preemptive cases. In columns 5 and 6 the debt crisis meaure only captures post-default cases. The control variables follow previous papers on the output cost of default. Significance levels denoted by $* * * \mathrm{p}<0.01,{ }^{* *} \mathrm{p}<0.05,{ }^{*} \mathrm{p}<0.10$. All regressions include country and year fixed effects. Robust standard errors clustered on the country level in parentheses. 


\section{Appendix E Regression Results: Market Exclusion}

Table E.1: Access to International Capital Markets During Debt Crises

\begin{tabular}{|c|c|c|c|c|c|c|}
\hline & All crises & $\begin{array}{l}\text { All crises, } \\
\text { with controls }\end{array}$ & $\begin{array}{l}\text { Preemptive } \\
\text { only }\end{array}$ & $\begin{array}{l}\text { Preemptive, } \\
\text { with controls }\end{array}$ & $\begin{array}{l}\text { Post-default } \\
\text { only }\end{array}$ & $\begin{array}{l}\text { Post-default, } \\
\text { with controls }\end{array}$ \\
\hline & (1) & (2) & (3) & (4) & (5) & (6) \\
\hline & coef/se & coef/se & coef/se & coef/se & coef/se & coef/se \\
\hline Debt Crisis (ongoing) & $\begin{array}{c}-0.25 * * * \\
(0.07)\end{array}$ & $\begin{array}{c}-0.23 * * * \\
(0.07)\end{array}$ & $\begin{array}{c}-0.41 * * * \\
(0.12)\end{array}$ & $\begin{array}{c}-0.36^{* * * *} \\
(0.11)\end{array}$ & $\begin{array}{l}-0.16 * * \\
(0.07)\end{array}$ & $\begin{array}{c}-0.15 * * \\
(0.06)\end{array}$ \\
\hline Post-Crisis (3 year lag) & $\begin{array}{c}-0.11 * * \\
(0.05)\end{array}$ & $\begin{array}{c}-0.11^{* *} \\
(0.05)\end{array}$ & $\begin{array}{l}-0.09 \\
(0.09)\end{array}$ & $\begin{array}{l}-0.10 \\
(0.09)\end{array}$ & $\begin{array}{l}-0.13 * * \\
(0.05)\end{array}$ & $\begin{array}{c}-0.14 * * * \\
(0.05)\end{array}$ \\
\hline Public Debt/GDP & & $\begin{array}{c}0.00 \\
(0.00)\end{array}$ & & $\begin{array}{l}-0.00 \\
(0.00)\end{array}$ & & $\begin{array}{c}0.00 \\
(0.00)\end{array}$ \\
\hline Reserves/Imports (\%) & & $\begin{array}{l}0.00^{* * *} \\
(0.00)\end{array}$ & & $\begin{array}{c}0.00^{* * *} \\
(0.00)\end{array}$ & & $\begin{array}{l}0.00^{* * *} \\
(0.00)\end{array}$ \\
\hline $\begin{array}{l}\text { Share of short-term debt } \\
\text { (in \%) }\end{array}$ & & $\begin{array}{l}-0.10^{*} \\
(0.06)\end{array}$ & & $\begin{array}{l}-0.10^{*} \\
(0.06)\end{array}$ & & $\begin{array}{l}-0.10^{*} \\
(0.06)\end{array}$ \\
\hline Real growth (in \%) & & $\begin{array}{c}0.00 \\
(0.00)\end{array}$ & & $\begin{array}{c}0.00 \\
(0.00)\end{array}$ & & $\begin{array}{c}0.00 \\
(0.00)\end{array}$ \\
\hline $\begin{array}{l}\text { Openness in \% } \\
\text { (Trade/GDP) }\end{array}$ & & $\begin{array}{l}-0.00 \\
(0.00)\end{array}$ & & $\begin{array}{l}-0.00 \\
(0.00)\end{array}$ & & $\begin{array}{l}-0.00 \\
(0.00)\end{array}$ \\
\hline Political Risk (ICRG) & & $\begin{array}{c}0.00 \\
(0.00)\end{array}$ & & $\begin{array}{l}0.00^{* *} \\
(0.00)\end{array}$ & & $\begin{array}{l}0.00^{*} \\
(0.00)\end{array}$ \\
\hline IMF program (start) & & $\begin{array}{l}-0.01 \\
(0.03)\end{array}$ & & $\begin{array}{l}-0.01 \\
(0.03)\end{array}$ & & $\begin{array}{l}-0.02 \\
(0.03)\end{array}$ \\
\hline Constant & $\begin{array}{c}0.34 * * * \\
(0.07)\end{array}$ & $\begin{array}{c}-1.53 * * * \\
(0.36)\end{array}$ & $\begin{array}{l}0.31^{* * *} \\
(0.08)\end{array}$ & $\begin{array}{c}-1.44^{* * *} \\
(0.38)\end{array}$ & $\begin{array}{l}0.27 * * * \\
(0.07)\end{array}$ & $\begin{array}{c}-1.66^{* * *} \\
(0.39)\end{array}$ \\
\hline Country Fixed Effects & Yes & Yes & Yes & Yes & Yes & Yes \\
\hline Year Fixed Effects & Yes & Yes & Yes & Yes & Yes & Yes \\
\hline Observations & 1,618 & 1,618 & 1,618 & 1,618 & 1,618 & 1,618 \\
\hline Countries & 81 & 81 & 81 & 81 & 81 & 81 \\
\hline Adjusted $R$-Squared & 0.113 & 0.157 & 0.109 & 0.153 & 0.097 & 0.146 \\
\hline
\end{tabular}

The table shows results from fixed effects OLS regressions. The dependent variable is a dummy for market access (placing bonds or loans in international primary markets), as measured from Dealogic. The main explantory variable is a dummy for ongoing crisis spells (default or renegotiation), as well as a lagged measure for years 1-3 after the crisis ends. In columns 3 and 4 the debt crisis measure (and its lag) only captures preemptive cases. In columns 5 and 6 the debt crisis meaure only captures post-default cases. All regressions include country and year fixed effects and errors are clustered on the country level. All control variables are lagged by one year. The controls include the share of public debt to GDP (from the IMF historical debt database), a measure of political risk (the compund country risk index from ICRG), the start of IMF programs (from the IMF website) and several variables from the WDI dataset: reserves to imports, the share of short-term debt in total debt, annual real growth and openness (trade/GDP). Countries with no access in the entire 1980-2010 period are automatically droped from the regression sample. Significance levels denoted by $* * * p<0.01,{ }^{* *} \mathrm{p}<0.05,{ }^{*} \mathrm{p}<0.10$. Robust standard errors clustered on country in parentheses. 


\section{Appendix F Model Parameters}

Table F.1: Model Parameters

\begin{tabular}{|c|c|c|c|}
\hline Parameter & Value & & Sources \\
\hline \multicolumn{4}{|l|}{ Symmetric } \\
\hline Risk aversion of borrower & $\sigma=2$ & & RBC Literature \\
\hline Risk-free interest rate & $r=0.017$ & & Arellano (2008) \\
\hline Output cost - post-default & $\lambda_{d}=0.02$ & & $\begin{array}{l}\text { Sturzenegger (2004), } \\
\text { Yue (2010) and others }\end{array}$ \\
\hline - preemptive & $\lambda_{p}=0.015$ & & Appendix D \\
\hline Country specific & (i) Argentina & (ii) Uruguay & \\
\hline Average endowment growth & $\mu_{g}=0.0093$ & $\mu_{g}=0.0065$ & Computed - MECON \\
\hline Std of endowment growth shock & $\sigma_{g}=0.0394$ & $\sigma_{g}=0.044$ & Computed - CBU \\
\hline Endowment growth AR(1) coefficient & $\rho_{g}=0.74$ & $\rho_{g}=0.21$ & Computed \\
\hline Discount factor & $\beta=0.80$ & $\beta=0.83$ & Computed \\
\hline Baseline bargaining power & $\theta=0.83$ & $\theta=0.57$ & Computed \\
\hline
\end{tabular}

Source: Ministry of Economy and Production in Argentina (MECON), Banco Central de Uruguay (Central Bank of Uruguay, CBU).

\section{Appendix G Computation Algorithm}

The procedure to compute the equilibrium distribution of the model is the following:

1. First, we set finite grids on the space of asset holding and endowment as $B=\left[b_{\min }, . ., 0\right]$ and $Y=\left[y_{\min }, . ., y_{\max }\right]$. The limits of the asset space are set to ensure that limits do not bind in equilibrium. Limits on endowments are large enough to include large deviations from mean value of shocks. We approximate the stochastic income process given by equation (30) using a discrete Markov chain of 41 equally spaced grids as in Tauchen (1986). Moreover, we compute the transition matrix based on the probability distribution $\mu\left(y_{t+1} \mid y_{t}\right)$.

2. Second, we set finite grids on the space of two sets of recovery rates at preemptive and post-default renegotiations. Limits of both sets of recovery rates are to ensure that they do not bind in equilibrium.

3. Third, we set the initial values for equilibrium bond prices, two sets of recovery rates. We use the risk-free bond price $\left(q_{0}=q^{f}=(1+r)^{-1}\right)$ for the baseline value of equilibrium bond price. We set $\delta_{0}=0.5$ and $\alpha_{0}=0.5$ and for the baseline recovery rates for preemptive and post-default renegotiation.

4. Fourth, given the baseline equilibrium bond price $\left(q_{0}=q^{f}\right)$, recovery rates at preemptive and post-default renegotiations $\left(\delta_{0}=0.5\right.$, and $\left.\alpha_{0}=0.5\right)$, we solve for the sovereign's optimization problem for good credit record $\left(h_{t}=0\right)$. This procedure finds the value function as well as the default decisions. We first guess the value function $\left(V^{0}, V^{D, 0}, V^{R, 0}, V^{E, 0}\right)$ and iterate it using the Bellman equation to find 
the fixed value $\left(V^{*}, V^{D *}, V^{R *}, V^{E *}\right)$, given the baseline bond price, recovery rates at two renegotiations. By iterating the Bellman function, we also derive the optimal asset policy function for every value $\left(a^{\prime}, a^{D}, a^{\prime R}, a^{\prime E}\right)$. For each credit history, we obtain the default choice, which requires a comparison of the value of defaulting and non-defaulting. By comparing these two values, we calculate the corresponding default set. Based on the default set, we also evaluate the default probability using the transition matrix. Similarly, we obtain results for the choice (and the value) of exchanging debt or postponing the exchange in a setting with an intermediate or bad credit record.

5. Fifth, using the default set in step (4), and the zero profit condition for foreign creditors, we compute the new price of discounted bond $\left(q_{1}\right)$. Then we iterate step (5) to have fixed value of equilibrium bond price.

6. Sixth, given the value function $\left(V^{*}, V^{D *}, V^{R *}, V^{E *}\right)$ and the value of autarky $\left(V^{A *}\right)$, we solve the bargaining problem at post-default renegotiation and compute new recovery schedule $\left(\alpha_{1}\right)$ for every $\left(b_{t}, y_{t}\right)$. Then we iterate step (4) and (5) to have the fixed optimal recovery rates $\left(\alpha_{1}^{*}\right)$.

7. Seventh, given the value function $\left(V^{*}, V^{D *}, V^{R *}, V^{E *}\right)$ and recovery rates at postdefault renegotiation $\left(\alpha_{1}^{*}\right)$, we compute the ex-ante value of the sovereign choosing not to take a preemptive option $V^{N O N-P R E *}$. We solve the bargaining problem at preemptive renegotiation and compute new recovery schedule $\left(\delta_{1}\right)$ for every $\left.\left(b_{t}, y_{t-1}\right)\right)$. Then, we iterate step (4), (5), (6) to have the fixed optimal recovery rates at preemptive restructuring $\delta_{1}^{*}$.

\section{Appendix H Equilibrium Properties for Uruguay}

Figure H.1 shows the equilibrium outcomes for or against a preemptive restructuring (ex-ante) and for default or repayment (ex-post) for the case of Uruguay. The underlying mechanisms driving these decisions are the same as in the Argentine case and as explained in the main text.

Let us start with the ex-ante choice for or against a preemptive restructuring. As shown in Panel A, the sovereign opts to restructure its debt preemptively when current debt is high and previous income is low (blue region). Correspondingly, Panel B shows the decision of default versus repayment after the income realization. In this case, the sovereign chooses to default and renegotiate its debt when current debt is high and current income level is low (red region).

In the combined Panel $\mathrm{C}$ we show the choice for or against a preemptive restructuring and the choice for default and repayment given mean previous income. The blue region corresponds to the ex-ante choice of a preemptive restructuring before observing current income. The region highlighted in red shows the default (and post-default restructuring) 
choice taken after the current income realization, while the repayment choice after the income shock is represented by the green region. Compared to Argentina, we find a smaller area of default choices and larger areas for repayment choices and preemptive debt exchanges (at the same levels of debt and income).

Figure H.1: Equilibrium choices for Uruguay

A: Choice for Preemptive Restr. (ex-ante)

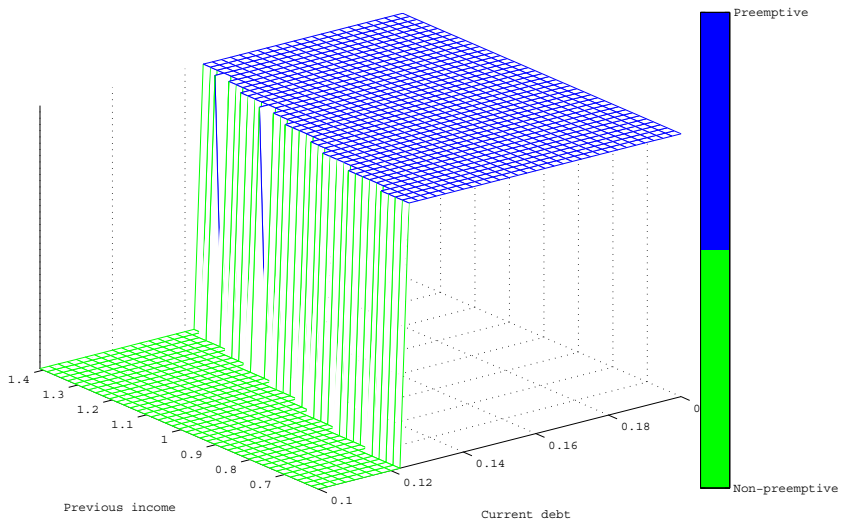

B: Default Choice (ex-post)

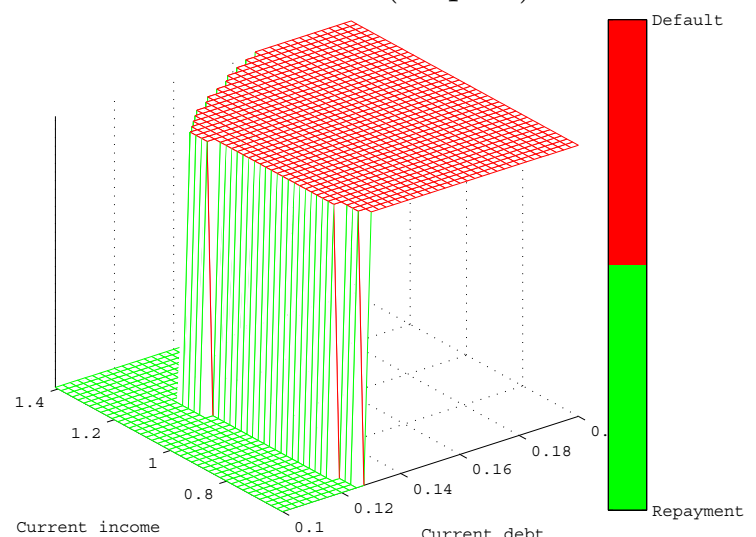

C: Combining the Choice for Preemptive Restructuring, Default and Repayment

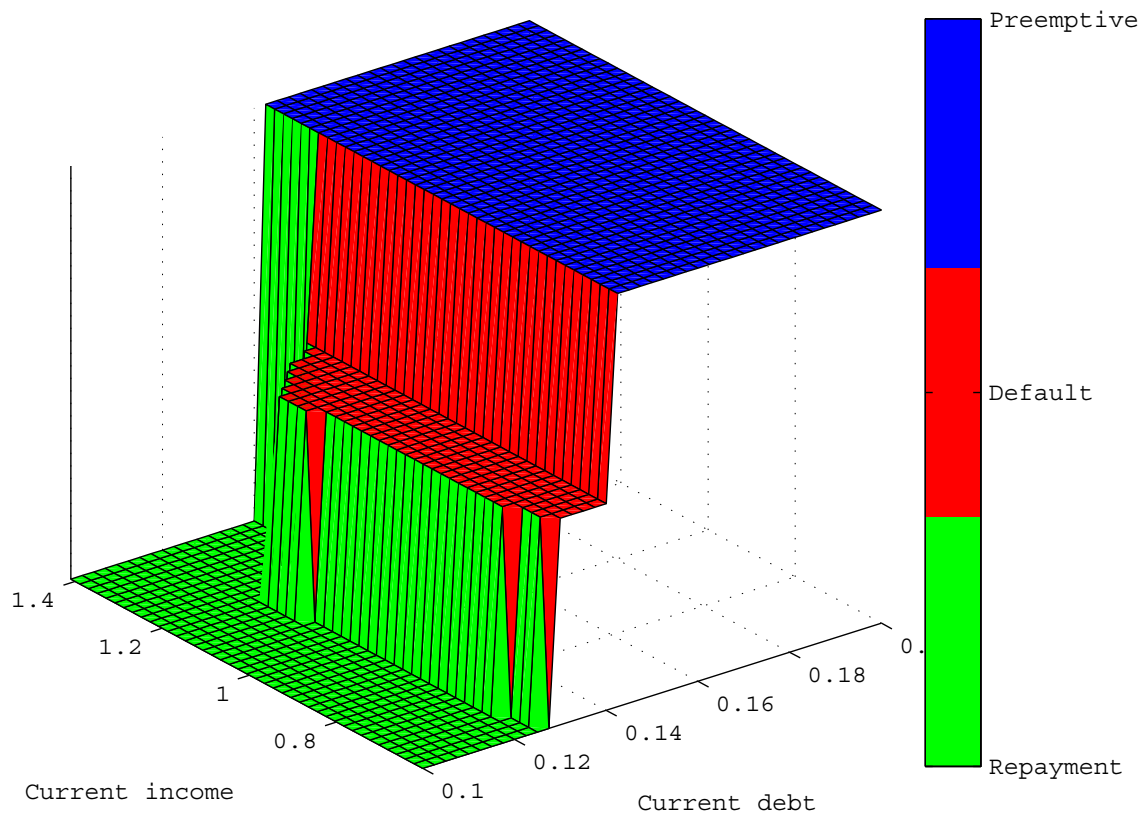




\section{Appendix I Argentina: Equilibrium Properties for Preemp- tive Negotiations}

Figure I.1: The Choice of Exchanging, Postponing or Not Restructuring (Argentina)

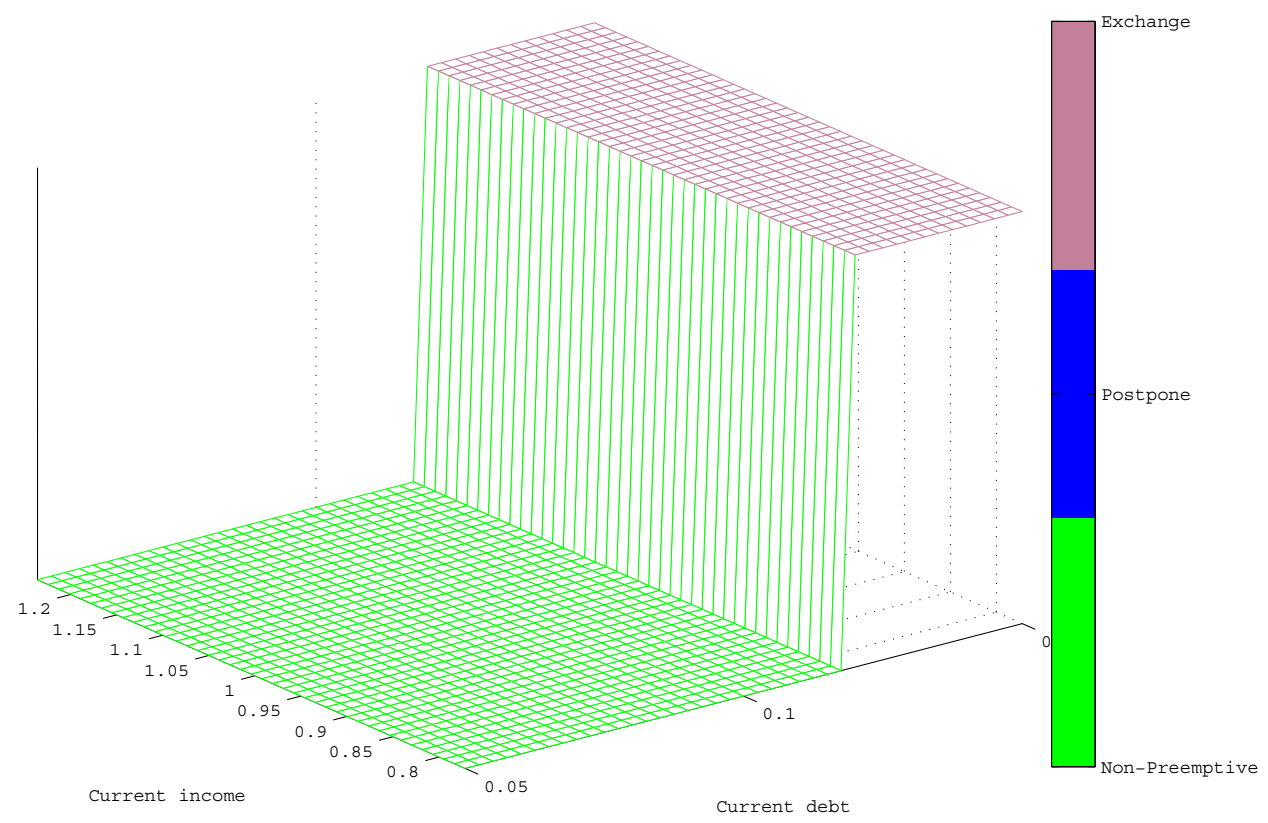




\section{Appendix J Business Cycle Statistics (ARG, URG)}

Table J.1: Baseline Calibration Results for Argentina and Uruguay

Argentina: Business Cycle Statistics

\begin{tabular}{|c|c|c|c|c|}
\hline & Data & Model & $\begin{array}{c}\text { Arellano } \\
\text { (2008) }\end{array}$ & $\begin{array}{c}\text { Yue } \\
(2010)\end{array}$ \\
\hline \multicolumn{5}{|l|}{ Before default / renegotiation } \\
\hline Consumption (std. dev.)/ Output (std. dev.) & 1.11 & 1.01 & 1.10 & 1.04 \\
\hline Trade Balance/Output (std. dev.) & 0.36 & 0.001 & 0.26 & - \\
\hline Corr. (Trade Balance, Output) & -0.87 & -0.14 & -0.25 & -0.16 \\
\hline \multicolumn{5}{|l|}{ During debt renegotiation } \\
\hline Consumption (std. dev.)/ Output (std. dev.) & 1.17 & 1.00 & - & - \\
\hline Trade Balance/Output (std. dev.) & 0.45 & 0.00 & - & - \\
\hline Corr. (Trade Balance, Output) & -0.97 & 0.00 & - & - \\
\hline \multicolumn{5}{|c|}{ Sources: Arellano (2008), Datastream, IMF WEO, MECON, Yue (2010). } \\
\hline \multicolumn{5}{|l|}{ Uruguay: Business Cycle Statistics } \\
\hline & Data & Model & \multicolumn{2}{|c|}{$\begin{array}{l}\text { Model without } \\
\text { preemptive } \\
\text { restructuring }\end{array}$} \\
\hline \multicolumn{5}{|l|}{ Before default / renegotiation } \\
\hline Consumption (std. dev.)/ Output (std. dev.) & 1.09 & 1.05 & \multicolumn{2}{|c|}{1.94} \\
\hline Trade Balance/Output (std. dev.) & 0.39 & 0.13 & \multicolumn{2}{|c|}{0.06} \\
\hline Corr. (Trade Balance, Output) & -0.77 & -0.06 & \multicolumn{2}{|c|}{-0.07} \\
\hline
\end{tabular}

Sources: IMF WEO, Banco Central de Uruguay. 


\section{Appendix K Uruguay: Calibration Robustness Analysis}

Our results on the phenomenon of preemptive restructurings hinge on three important parameters: bargaining power, the (lower) output costs for preemptive restructuring, and the discount rate. Together they determine the sovereign's restructuring choice for or against a preemptive negotiation, as well as the equilibrium recovery rates. For sensitivity analysis, Table K.1 reports how changes in these key parameter values influence the main statistics in the preemptive Uruguayan case. For brevity, we omit this for the case of post-default restructurings, also because previous papers such as Bi (2008), Yue (2010), and Asonuma (2012) have already assessed the sensitivity of these post-default parameters extensively.

An increase in bargaining power for the sovereign strongly reduces average recovery rates at preemptive restructurings and increases average bond spreads. Both is intuitive: as bargaining power gets higher, the sovereign succeeds in negotiating lower recovery rates compared to the baseline case. This in turn leads to an increase in average bond spreads as shown in equations (25) and (26).

An increase in the output costs of preemptive restructurings (closer to those of postdefault deals), leads to a lower probability of default. The sovereign is less willing to restructure its debt preemptively and has a lower capacity to pay high recovered debt after the completion of a preemptive exchange, resulting in lower recovery rates. Changes in the output costs influence the average output deviation only slightly. This is because preemptive renegotiations are typically short so that the average output deviation depends more on the income realization, particularly on how the realized income level per se deviates from the trend, and not so much on the output cost during renegotiation.

Table K.1: Sensitivity Analysis (Uruguay)

\begin{tabular}{|c|c|c|c|c|c|c|c|c|c|}
\hline & \multicolumn{3}{|c|}{ Bargaining power $(\theta)$} & \multicolumn{3}{|c|}{ Output costs (preemptive $\lambda$ ) } & \multicolumn{3}{|c|}{ Discount rate $(\beta)$} \\
\hline & 0.57 & 0.70 & 0.80 & 0.01 & 0.015 & 0.019 & 0.75 & 0.80 & 0.95 \\
\hline Default / Restruct. Prob. (\%) & 3.95 & 4.03 & 4.07 & 4.30 & 3.95 & 3.42 & 4.70 & 3.95 & 2.87 \\
\hline Avg. Recovery Rates (\%) & 83.0 & 65.7 & 52.7 & 80.0 & 83.0 & 89.5 & 79.1 & 83.0 & 41.7 \\
\hline Bond Spreads: Average (\%) & 1.71 & 2.03 & 2.14 & 2.29 & 1.71 & 1.49 & 4.32 & 1.71 & 1.33 \\
\hline Bond Spreads: Std. Dev. (\%) & 2.62 & 2.64 & 2.64 & 2.72 & 2.62 & 2.62 & 3.20 & 2.62 & 2.44 \\
\hline Avg. Debt/GDP ratio (\%) & 12.3 & 8.9 & 7.2 & 12.3 & 12.3 & 12.3 & 12.1 & 12.3 & 13.7 \\
\hline Restructuring Choice & Preemptive & Preemptive & Preemptive & Preemptive & Preemptive & Preemptive & Preemptive & Preemptive & Preemptive \\
\hline
\end{tabular}

A higher discount rate reduces the probability of default/restructuring and the average bond spreads and increases the average debt level. As the sovereign becomes more patient and less willing to default, it can accumulate higher debt and has a smaller probability of default/restructuring. Importantly, changes in these three parameter values do not alter the sovereign's choice of preemptive restructuring (lowest row in Table K.1). 